Article

\title{
Growth Hormone Upregulates Mediators of Melanoma Drug Efflux and Epithelial-to-Mesenchymal Transition In Vitro and In Vivo
}

\author{
Yanrong Qian ${ }^{1,+} \mathbb{D}^{-}$, Reetobrata Basu ${ }^{1,+} \mathbb{D}^{\mathbb{D}}$, Samuel C. Mathes ${ }^{1,2}$, Nathan A. Arnett ${ }^{1,3}$, \\ Silvana Duran-Ortiz ${ }^{1,2,4}$, Kevin R. Funk ${ }^{1,2,4}$, Alison L. Brittain ${ }^{1,4,5}$, Prateek Kulkarni ${ }^{1,2,4}(\mathbb{D}$, \\ Joseph C. Terry ${ }^{1,2}$, Emily Davis ${ }^{1,2,4}$, Jordyn T. Singerman ${ }^{1,2}$, Brooke E. Henry ${ }^{1}$, Edward O. List ${ }^{1}$, \\ Darlene E. Berryman 1,5 (D) and John J. Kopchick 1,4,5,* \\ 1 Edison Biotechnology Institute, Ohio University, Athens, OH 45701, USA; qiany@ohio.edu (Y.Q.); \\ basu@ohio.edu (R.B.); mathes@ohio.edu (S.C.M.); na366913@ohio.edu (N.A.A.); \\ sd504111@ohio.edu (S.D.-O.); funkk@ohio.edu (K.R.F.); ab647713@ohio.edu (A.L.B.); \\ pk585316@ohio.edu (P.K.); jt321916@ohio.edu (J.C.T.); ed218514@ohio.edu (E.D.); js243112@ohio.edu (J.T.S.); \\ bh997614@ohio.edu (B.E.H.); list@ohio.edu (E.O.L.); berrymad@ohio.edu (D.E.B.) \\ 2 Department of Biological Sciences, Ohio University, Athens, OH 45701, USA \\ 3 Russ College of Engineering, Ohio University, Athens, OH 45701, USA \\ 4 Molecular Cellular Biology Program, Ohio University, Athens, OH 45701, USA \\ 5 Department of Biomedical Sciences, Heritage College of Osteopathic Medicine, Ohio University, \\ Athens, OH 45701, USA \\ * Correspondence: kopchick@ohio.edu; Tel.: +1-740-593-4534; Fax: +1-740-593-4795 \\ + These authors contributed equally to this work.
}

Received: 15 October 2020; Accepted: 2 December 2020; Published: 4 December 2020

Simple Summary: Growth hormone (GH) action is strongly implicated in the progression and therapy resistance in several types of solid tumors which overexpress the GH receptor (GHR). The aim of our study was to characterize the effects of GH and its downstream effector insulin-like growth factor 1 (IGF-1) on melanoma using in vitro and in vivo models. We confirmed an IGF-1-independent role of elevated circulating GH in upregulating key mechanisms of therapy resistance and malignancy with analyses conducted at the molecular and cellular level. We identified that GH upregulates key mechanisms of therapy resistance and metastases in melanoma tumors in an IGF-1 dependent and independent manner by upregulating multidrug efflux pumps and EMT transcription factors. Our study reveals that $\mathrm{GH}$ action renders an intrinsic drug resistance phenotype to the melanoma tumors-a clinically crucial property of GH verifiable in other human cancers with GHR expression.

\begin{abstract}
Growth hormone (GH) and the GH receptor (GHR) are expressed in a wide range of malignant tumors including melanoma. However, the effect of GH/insulin-like growth factor (IGF) on melanoma in vivo has not yet been elucidated. Here we assessed the physical and molecular effects of GH on mouse melanoma B16-F10 and human melanoma SK-MEL-30 cells in vitro. We then corroborated these observations with syngeneic B16-F10 tumors in two mouse lines with different levels of GH/IGF: bovine GH transgenic mice (bGH; high GH, high IGF-1) and GHR gene-disrupted or knockout mice (GHRKO; high GH, low IGF-1). In vitro, GH treatment enhanced mouse and human melanoma cell growth, drug retention and cell invasion. While the in vivo tumor size was unaffected in both bGH and GHRKO mouse lines, multiple drug-efflux pumps were up regulated. This intrinsic capacity of therapy resistance appears to be GH dependent. Additionally, epithelial-to-mesenchymal transition (EMT) gene transcription markers were significantly upregulated in vivo supporting our current and recent in vitro observations. These syngeneic mouse melanoma models of differential
\end{abstract}


GH/IGF action can be valuable tools in screening for therapeutic options where lowering GH/IGF-1 action is important.

Keywords: growth hormone; growth hormone receptor; insulin-like growth factor-1; melanoma; multidrug efflux pumps; epithelial-to-mesenchymal transition

\section{Introduction}

Accumulating evidence implicates growth hormone (GH) in the development and progression of a wide range of malignancies [1-7], including breast [8-15], prostate [16,17], colorectal [18,19], glioma [20], pancreatic [21], thyroid [22], liver [23] and endometrial cancers [24,25]. GH is a peptide hormone produced by pituitary somatotrophs and acts on multiple tissues including bone, muscle, fat, liver, pancreas, heart, thymus and kidney. GH is anabolic in bones and muscle, while catabolic in adipose tissue, and exerts distinct metabolic effects on liver, muscle, and fat throughout the lifespan of an individual [26]. GH's actions are mediated first through binding to the preformed GHR dimer, which activates intracellular signal transduction pathways known to be critical for GH's multiple effects $[27,28]$. These pathways include the Janus kinase-2 (JAK-2) and signal transducers and activators of transcription 5 (STAT5), STAT1 and STAT3, the c-Src mediated p44/42 mitogen-activated protein kinase (ERK or MAPK), and the phosphoinositide 3-kinase (PI3K) pathways [27-30]. Upregulation of selected components of these pathways has been observed in a wide range of malignant GH-responsive tumors, supporting the involvement of GH-induced GHR activation in tumor growth.

IGF-1 is another potent growth factor, which has autocrine, paracrine and endocrine effects and is an important drug target in cancer [31-33]. GH induces the majority of circulating IGF-1 production primarily in the liver as well as in several other tissues. Both GH and IGF-1 are important components of GH-induced intracellular signaling pathways, and together constitute the GH/IGF-1 axis. In terms of growth, GH and IGF-1 have both unique and overlapping actions [34,35]. It is of particular interest to be able to resolve IGF-dependent and -independent effects of GH related to cancer incidence and progression. Mouse models with a dysregulated GH/IGF-1 axis-bGH (bovine GH transgenic) and GHRKO (GHR knock out) - are valuable for studying these differential effects. bGH mice have high GH ( $>600 \mathrm{ng} / \mathrm{mL} ; \sim 400$-fold increase) and high circulating IGF-1 ( $500 \mathrm{ng} / \mathrm{mL} ; \sim 2$-fold increase) [36,37]. In contrast, GHRKO mice have a germline inactivating mutation in the GHR. These mice are small, with low levels of IGF-1 ( $50 \mathrm{ng} / \mathrm{mL}$; 11-fold decrease), but high levels of GH ( 120 ng/mL; 12-fold increase), and are thus GH insensitive [38]. Utilization of these two mouse lines allows for a differential evaluation of the effects of elevated GH versus IGF-1 on cancers in vivo [37,38].

Several recent reviews have highlighted the profile of GH action in multiple types of cancer $[6,7,39,40]$. Lobie and colleagues have reported that GH expression in tumors predicts a worse survival outcome in patients with mammary and endometrial carcinoma [41]. Melmed et al. have demonstrated through a series of elegant studies that GH induces DNA damage and abrogates DNA damage repair (DDR) in normal colon tissues, alongside decreasing p53 expression by suppressing ATM kinases [42-44]. These actions of GH increase colon polyps and potentially direct oncogenesis and cancer progression in the colon; and indeed colon cancer incidence rates were found upregulated by several studies on acromegaly patients [22,45]. Furthermore, autocrine human (h) GH promotes oncogenicity, cell growth, survival, migration, invasion, and induces tumor angiogenesis and resistance to radiation treatment in mammary, endometrial and hepatocellular carcinomas [3,9,11,15,24,25,46-54].

Melanoma is one of several skin cancers and develops from transformation of the pigment-containing cells known as melanocytes. It represents less than one percent of cases but accounts for the most deaths among skin cancers [55]. The incidence of melanoma has increased over the past four decades, resulting in an intensified need to understand the mechanisms of melanoma 
development, to improve the effectiveness of available treatments, and to develop efficient and novel anticancer therapies.

To date, multiple in vitro studies conducted by our group and others have contributed towards the overall understanding of the effects of the GH/IGF axis on melanoma cells. We have previously shown that among nine types of human cancers in the National Cancer Institute (NCI-60) panel of 60 cell lines, all of the melanoma cell lines exhibit the highest levels of GHR, and the treatment of these cells with recombinant hGH resulted in increased melanoma proliferation and activation of oncogenic signaling intermediates [56]. We have also shown that siRNA-mediated GHR knockdown in human melanoma cells attenuated tumor progression, epithelial-to-mesenchymal transition (EMT) [57] and sensitized these cells to chemotherapy by attenuating expression of ATP-binding cassette (ABC) multidrug efflux pumps [58]. We further reported that GH upregulates the expression and activity of melanocyte-inducing transcription factor (MITF) via JAK2-STAT5 and SRC signaling in human melanoma cells, thereby inducing drug sequestration in melanosomes [59]. The ability of IGF-1 to enhance metastasis of melanoma cells through upregulation of EMT has also been reported [60]. However, to date, in vivo validation of the role of GH in melanoma is absent.

As an extension of our in vitro studies, we sought to study the effects of GH/IGF- 1 on melanoma progression in vivo. B16-F10 mouse melanoma cells are widely used and well-studied [61]. The B16-F10 cell line was originally derived from C57BL/6J mice; the same background strain of both bGH transgenic and GHRKO mice. By inoculating this cell line into bGH and GHRKO mice, we were able to test the hitherto unknown role of GH and/or IGF-1 in melanoma progression in vivo.

\section{Results}

\subsection{Melanoma Cells Are Responsive to GH Treatment}

Using realtime RT-qPCR, immunocytochemistry and western blotting, we evaluated RNA and protein expression levels of GH and GHR, as well as IGF-1 and IGF-1R in human and mouse melanoma cell lines. Both B16-F10 mouse melanoma and SK-MEL-30 human melanoma cells express Ghr and Igf-1r RNA, while SK-MEL-30 also expressed GH1 and IGF-1 transcripts (Figure 1A,B). Further, immunostaining with GHR-specific antibody revealed an abundant distribution of GHR on both B16-F10 and SK-MEL-30 cells (Figure 1C), while western-blot analysis revealed robust expression of IGF-1R in both cell lines (Figure 1D and Figure S9). In fact, the GHR expression on the melanoma cell lines was markedly higher than the same in non-transformed skin fibroblasts (Figure S1A). B16-F10 cells did not express detectable levels of $G h$ or Igf-1 RNA, indicating perhaps a greater dependence on either circulating or paracrine GH or IGF-1 from the tumor microenvironment, rather than autocrine production. Even following $48 \mathrm{~h}$ of GH treatment, the supernatants of GH-treated B16-F10 cells showed no increase in IGF-1 protein levels (Figure S1E). GHR activation, following the addition of GH, can be evaluated by testing the phosphorylation states of signature GH-induced signaling intermediates, e.g., STAT5 as well as STATs 1 and 3, SRC, ERK1/2 (p42/44 MAPK), and AKT [27,28]. These signaling proteins have been shown to contribute to tumor proliferation and survival [28,62]. We observed a GH-induced dose-dependent increase in the phosphorylation of STATs 1 and 5, in both B16-F10 and SK-MEL-30 cells in vitro, while STAT3 phosphorylation was not affected (Figure 1E,F and Figure S9). This was distinct within 15 min of GH treatment in B16-F10 mouse melanoma cells (Figures S1B and S9), consistent with our previous observations in the following human melanoma cells: SK-MEL-5, SK-MEL-28, MALME-3M, and MDA-MB-435 [57,58]. Additionally, $500 \mathrm{ng} / \mathrm{mL}$ bGH treatment in B16-F10 cells and $250 \mathrm{ng} / \mathrm{mL}$ hGH treatment in SK-MEL-30 cells, respectively, upregulated phosphorylation states of ERK1/2, AKT, and SRC (Figure 1G,H and Figure S9). Furthermore, to assess a physiological effect of up regulated GHR and IGF1-R and active GH signaling, we assessed cell proliferation in presence of extended GH treatments or following siRNA mediated GHR knockdown. High doses of exogenous GH did not significantly change the growth-rate in B16-F10 cells (Figure 1I), although $250 \mathrm{ng} / \mathrm{mL} \mathrm{GH}$ did significantly increase SK-MEL-30 cell growth over $48 \mathrm{~h}$ (Figure 1J). However, in both B16-F10 
and SK-MEL-30 cells, there was a consistent and significant reduction in cell growth following GHR knockdown (Figure 11,J). 
A

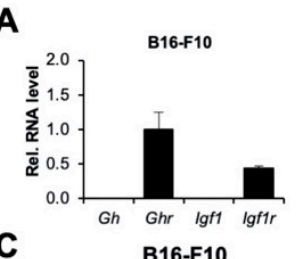

C

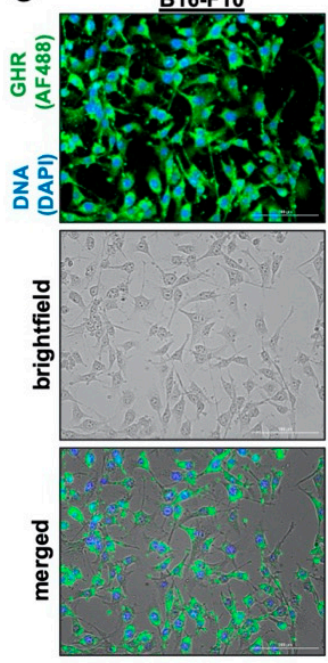

D

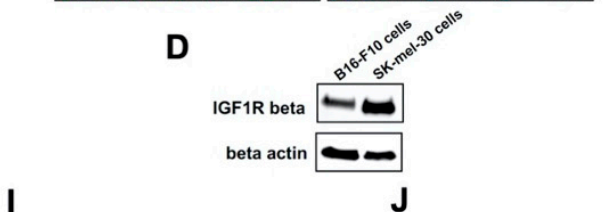

B

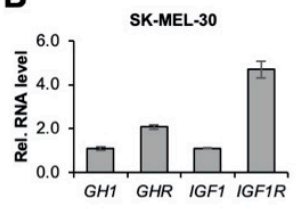

SK-MEL-30
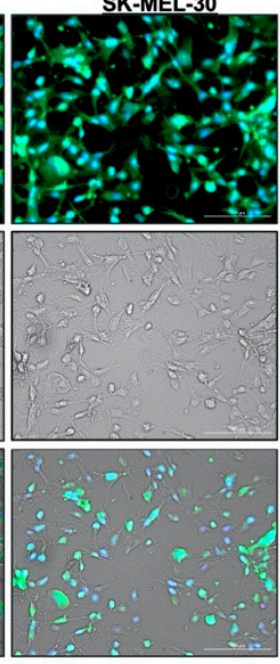

E

B16-F10 - intracellular signaling $\mathrm{bGH}(\mathrm{ng} / \mathrm{mL}) \quad 0 \quad 50 \quad 500$
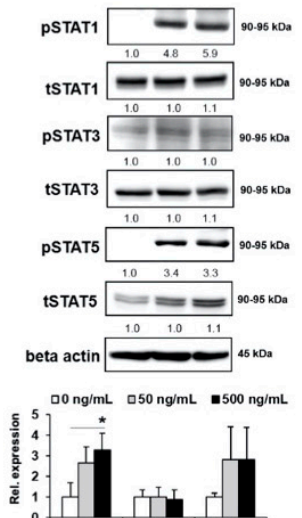

G

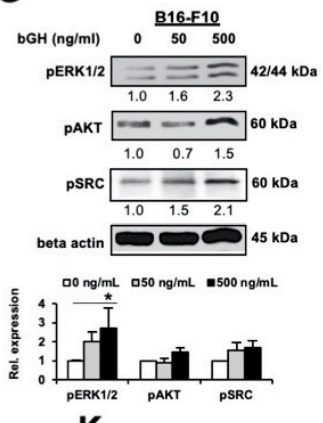

K
$\mathbf{F}$

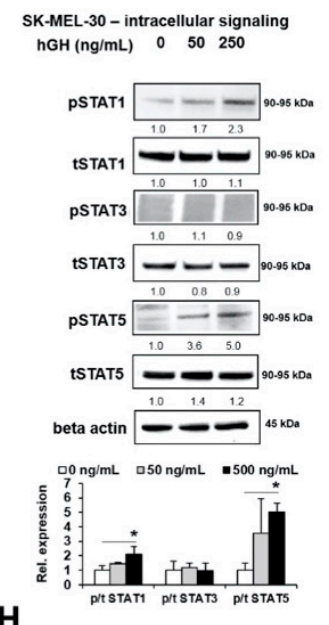

H

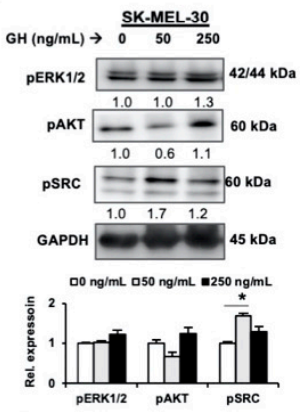

L

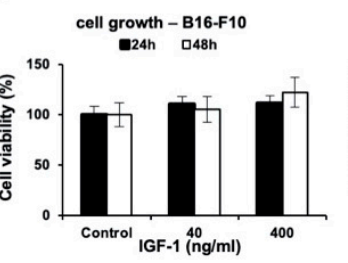

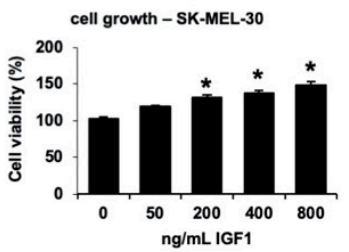

Figure 1. Melanoma cells are responsive to GH treatment in vitro. (A) Relative RNA expression was quantified for Gh, Ghr, Igf1 and Igf1r genes in B16-F10 mouse melanoma cells $(\mathrm{n}=3)$. (B) Relative RNA expression was quantified for GH, GHR, IGF1 and IGF1R genes in SK-MEL-30 human melanoma cells, normalized against GAPDH $(\mathrm{n}=3)$. (C) B16-F10 and SK-MEL-30 cells were stained with GHR antibody. Top panels present cellular DNA stained with DAPI (blue) and fluorescent signals from AF488-tagged anti-GHR antibody (green). Middle panels represent brightfield views while bottom panels represent merged views (20× magnification; scale bar represents $100 \mu \mathrm{m})$. (D) Expression of IGF1R-beta was detected in B16-F10 and SK-MEL-30 cells via western blotting. (E) Representative images of western blot analyses of phosphorylation (p) and total (t) levels of STATs 1, 3 and 5 in bovine $\mathrm{GH}(\mathrm{bGH})$ treated B16-F10 melanoma cell lysates. Cells were treated for $30 \mathrm{~min}$ and lysed. Densitometry analysis was performed and normalized against $\beta$-actin. The fold changes relative to control are labeled under each band. The ratio of $\mathrm{p} / \mathrm{t}$ protein levels are quantified against controls and shown in bar graphs $(\mathrm{n}=3)$. (F) Similar results for SK-MEL-30 cells treated with human (h) GH for 30 min were obtained. (G,H) Changes in GH signaling proteins, pERK1/2, pAKT and pSRC, in B16-F10 cells and SK-MEL-30 cells treated with bGH or hGH for $48 \mathrm{~h}$. Protein levels were normalized against $\beta$-actin or GAPDH. (I) Changes in cell proliferation of B16-F10 cells transfected with scramble or GHR-targeted siRNA (siRNA-2), after 48-h treatment with bGH. (J) Similar results were observed in SK-MEL-30 cells transfected with scramble (si-scr) or GHR-targeted siRNA (si-GHR), after 48-h treatment with hGH (* as compared with si-scr group, \# as compared with no treatment group). (K) Changes in cell proliferation of B16-F10 cells treated with increasing doses of IGF-1 for 24 and $48 \mathrm{~h}$. (L) Changes in cell proliferation of SK-MEL-30 after 48-h treatment with recombinant human IGF-1 $(n=5)$. Data are presented as mean \pm standard deviation $(*, p<0.05$, Mann-Whitney U test). 
These findings collectively indicate that both mouse and human melanoma cells express functional GHRs that are responsive to GH, shown by increased GH-induced signaling intermediates and melanoma growth in vitro. As both B16-F10 and SK-MEL-30 cells express high levels of IGF-1R, we assessed IGF-1 dose-dependent cell growth up to $48 \mathrm{~h}$ after treatment. We saw no significant increase in B16-F10 growth by up to $400 \mathrm{ng} / \mathrm{mL}$ IGF-1 treatment (Figure 1K), although above $200 \mathrm{ng} / \mathrm{mL}$, IGF-1 significantly upregulated SK-MEL-30 growth in vitro (Figure 1L). Thus, the B16-F10 differed from the human SK-MEL-30 cells in the lack of autocrine GH or IGF-1 production but were alike in displaying abrogated cell growth following GHR blockade (Figure 1I). This along with the active and consistent intracellular signaling in both cell lines indicates that GH may contributes to some other intrinsic cellular phenomenon in melanoma cells, distinct from mitotic proliferation. We proceeded to evaluate the effect of the GH/IGF-1 axis in vivo in mouse syngeneic model for melanoma in C57BL/6J male and female mice transgenic for bovine $\mathrm{GH}$ (bGH mice) and in mice insensitive to $\mathrm{GH}$ action due to a dysfunctional GHR 'knock-out' (GHRKO mice).

\subsection{In Syngeneic Mouse Melanoma Models, Elevated GH or IGF-1 Did Not Affect Growth Rate of B16-F10 Tumors In Vivo}

The syngeneic mouse melanoma models are unique as the bGH mice present supraphysiological GH and IGF-1 levels; while the GHRKO mice present supraphysiological GH but highly suppressed IGF-1 levels [36-38]. Results derived from these mice, when compared to their WT counterparts with physiological levels of GH and IGF-1, allow us to tease out the independent or perhaps synergistic effect of GH and IGF-1 on the inoculated mouse melanomas. Accordingly, the bGH and GHRKO mice and their WT counterparts were subcutaneously inoculated with B16-F10 cells, and the size of the resulting tumors were measured over time. We did not observe a significant difference in tumor volumes (Figure 2A-D) or weights (Figure 2E,F), in either the bGH (Figure 2A,B,E) or the GHRKO (Figure 2C,D,F) mice relative to controls. However, we did observe a non-significant trend towards elevated tumor size and weight specifically in female bGH (Figure 2B,E) and GHRKO (Figure 2D,F) mice compared to controls. In vivo, the implanted tumors were under the effect of both endocrine and autocrine/paracrine GH and IGF-1. Therefore, next we assessed the tumoral production of GH and IGF-1. There was no significant difference in the tumoral transcript levels of Ghr, Igf-1, and Igf-1r between the mice (Figure S2). Contrary to a significantly low level of $G h$ and Igf-1 transcript levels in vitro (Figure 1A), we detected GH and IGF-1 proteins in the tumor lysates in vivo. Interestingly, there was no difference in tumoral GH or IGF-1 levels in male bGH and GHRKO vs. corresponding WT mice (Figure 2G-J). However, female mice presented significantly higher autocrine IGF-1 levels in bGH mice compared to WT controls (Figure 2I) and significantly higher autocrine GH levels in the GHRKO vs. WT mice (Figure 2H). Furthermore, we assessed the extent of GH induced intracellular signaling in the isolated tumors from $\mathrm{bGH}$ and GHRKO and their corresponding WT mice. 
A
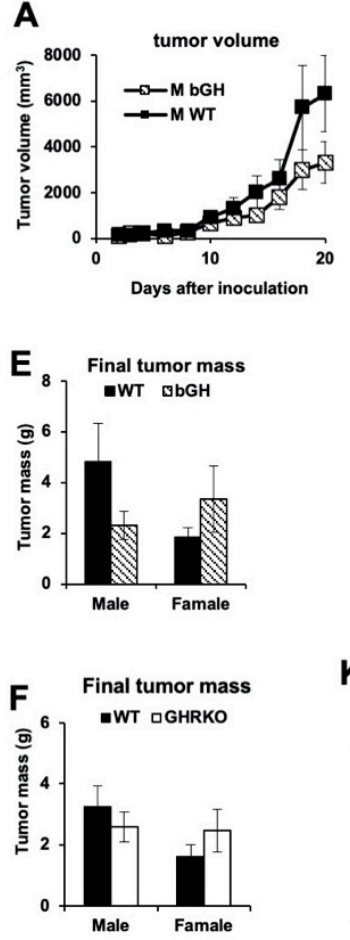

B

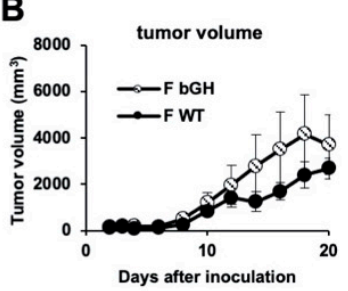

C

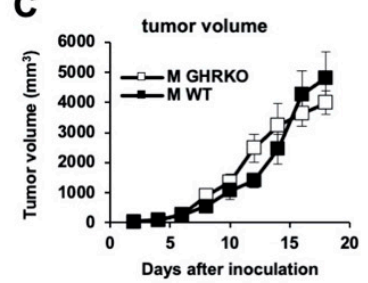

D

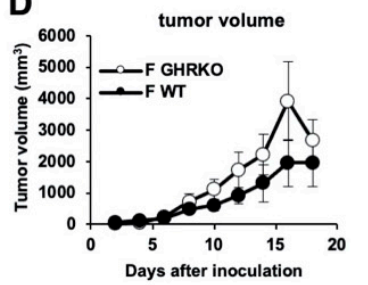

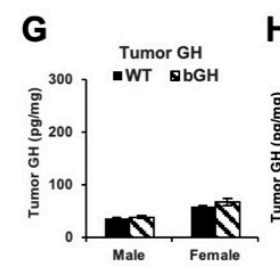
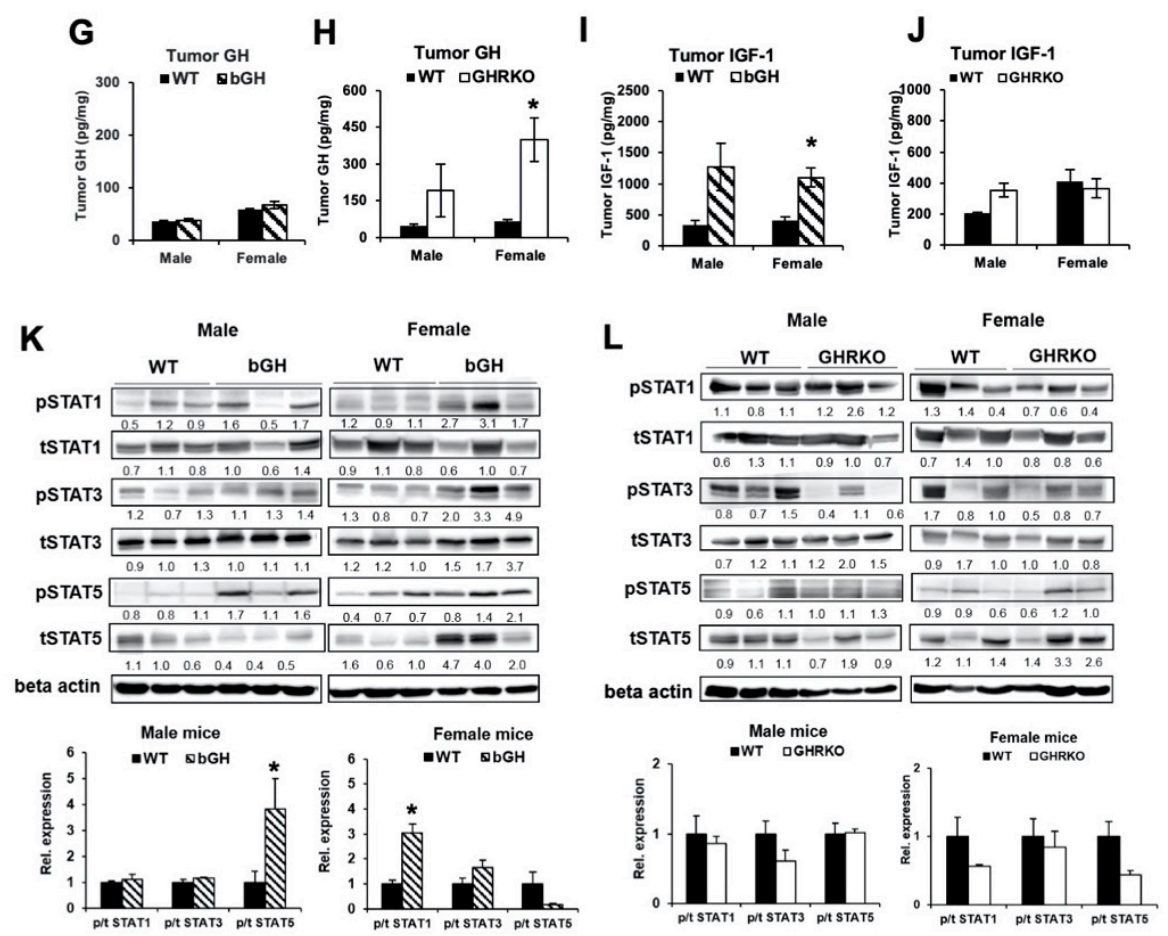

Figure 2. Subcutaneous B16-F10 mouse melanoma growth in bGH and GHRKO syngeneic mice. (A) Subcutaneous B16-F10 tumor growth in male bGH $(n=5)$ vs. WT mice $(n=6)$. (B) Subcutaneous B16-F10 tumor growth in female bGH $(n=7)$ and WT mice $(n=6)$. (C) Subcutaneous B16-F10 tumor growth in male GHRKO $(\mathrm{n}=6)$ vs. WT $(\mathrm{n}=8)$ mice. (D) Subcutaneous B16-F10 tumor growth in female GHRKO $(n=4)$ and WT mice $(n=5)$. Tumor sizes were analyzed by repeated measures (SPSS). (E) Weight of subcutaneous B16-F10 tumors from bGH vs. WT mice at dissection. (F) Weight of subcutaneous B16-F10 tumors from GHRKO vs. WT mice at dissection. (G) GH levels were measured in protein lysates isolated from tumors of bGH and WT mice using ELISA and normalized to total protein concentrations $(\mathrm{n}=4)$. $(\mathbf{H})$ Similar $\mathrm{GH}$ measurements were performed in protein lysates isolated from tumors of GHRKO and WT mice (males $n=3$, females $n=4$ ). (I) IGF-1 levels were measured in protein lysates isolated from tumors of bGH and WT mice using ELISA and normalized to total protein concentrations $(n=4)$. (J) Similar IGF-1 measurements were performed in protein lysates isolated from tumors of GHRKO and WT mice (males $n=3$, females $n=4$ ). (K) Representative images of western blot analysis of phosphorylation (p) and total ( $\mathrm{t}$ ) levels of STAT1, STAT3 and STAT5 in protein lysates isolated from tumors of bGH and WT mice. Densitometry analysis was performed and normalized against $\beta$-Actin. The relative expression levels (fold change relative to WT) are labeled under each band. The ratio of phosphorylated vs. total protein levels in tumors from bGH and WT mice are presented in bar graphs $(n=4)$. (L) Representative images of western blot analysis of phosphorylation and total levels of STAT1, STAT3, and STAT5 in protein lysates isolated from tumors of GHRKO and WT mice. (males $\mathrm{n}=3$, females $\mathrm{n}=4$ ). Data are presented as mean \pm standard errors ${ }^{*}, p<0.05$, unpaired student's $t$-test).

We did observe a significantly higher level of phosphorylation of STAT5 in the male bGH vs. the WT mice (Figure 2K and Figure S9) and a significantly higher phosphorylation of STAT1 in the tumors 
in the female bGH vs. the WT mice (Figure 2K and Figure S9); while the GHRKO vs. WT mice did not reveal a significant difference in STAT signaling (Figure 2L and Figure S9).

$\mathrm{GH}$ is also known to affect glucose metabolism in various tissues [63]. Thus, we tested glycolysis and oxidative phosphorylation in these tumors. The results suggested that neither was affected by elevated GH action in vivo, similar to in vitro observations, at least at the GH concentrations tested (Figure S3). Therefore, we proceeded to inquire into the effects of GH and GHR in driving intrinsic drug resistance by upregulating $\mathrm{ABC}$-cassette containing multidrug transporters [58] and EMT mediators [57], as we recently described in human melanoma cells in vitro.

\subsection{Elevated GH Drives Expression of ATP-Binding Cassette (ABC-Type) Multidrug Efflux Pumps in Melanoma Tumors In Vitro and In Vivo}

We analyzed the effect of $\mathrm{GH}$ action on the expression levels of $\mathrm{ABC}$ transporter expression both in cell culture as well as in the tumor lysates from male and female bGH and GHRKO vs. their corresponding controls. The RNA expression levels of different ABC-type pumps based on their known critical role in conferring chemoresistance [58,64-70] were quantified. In B16-F10 cultured cells, the RNA levels of $A b c b 1 a, A b c g 1$ and $A b c g 2$ were markedly upregulated by 5-fold, 3-fold and 2-fold respectively, following 24- and 48-h exposure to 50 or $500 \mathrm{ng} / \mathrm{mL}$ bGH compared to untreated controls (Figure $3 \mathrm{~A}-\mathrm{C}$ ). In human SK-MEL-30 melanoma cells treated with $250 \mathrm{ng} / \mathrm{mL}$ hGH in vitro increased expression of $A B C B 5, A B C B 8, A B C G 1$ and $A B C G 2$ RNA (Figure 3D). At the protein level, B16-F10 cells treated with bGH showed an upregulation of the expression of ABCB1, ABCG1, and ABCG2 (Figure 3E and Figure S9), similar to the trend in RNA expression. We also observed a robust increase at the protein level of ABCB1 and ABCG2 in the SK-MEL-30 cells in a dose-dependent manner with GH (Figure 3F and Figure S9). In vitro, we also assessed IGF-1 dose needed for elevated RNA expression of multiple $\mathrm{ABC}$ transporters. IGF-1 only modestly and non-significantly increased mainly the Abcc type transporter levels (Figure S4E and Table 1). To test whether the GH induced increase in $\mathrm{ABC}$ transporter levels lead to a biological effect of increased efflux capacity, we performed a drug retention assay using DiOC2 dye as a drug surrogate. The results indicate $\mathrm{ABCB} 1$ and to a lesser extent ABCC1 and ABCG2 transporter activities. Both B16-F10 and SK-MEL-30 cells, showed 12-15\% lower (Figure 3G) and 12-19\% lower (Figure 3H,I) dye retained respectively in GH treated samples compared to controls (Figure 3G-I).

In vivo, we found that both $A B C$ transporter RNA and protein expression were elevated in the implanted melanoma tumors in bGH and GHRKO mice relative to controls. The RNA levels of ABC transporters in tumors from bGH mice were upregulated significantly for $A b c b 8(p=0.041), A b c c 2(p=$ 0.011), $A b c c 4(p=0.021), A b c g 1(p=0.047)$, and $A b c g 2(p=0.016)$ (Figure 3J,L). In addition, the tumors from GHRKO mice had significantly higher levels of $A b c b 1 a(p=0.008), A b c b 8(p=0.020), A b c g 1$ ( $p=$ 0.033), and $A b c g 2$ ( $p=0.021$ ) (Figure $3 \mathrm{~K}, \mathrm{~L})$, relative to their WT littermates. As summarized in the heatmap (Figure 3L), tumors from bGH mice, with high GH and high IGF-1, had a general increase in multiple $\mathrm{ABC}$ transporters tested. Whereas in the tumors from GHRKO mice, with high GH but very low IGF-1, the increase was lost specifically for $A b c c 2$ and $A b c c 4$, suggesting that: (i) IGF-1, might be particularly responsible for the increase in $A b c c 2$ and $A b c c 4$ expression in tumors in vivo; and (ii) GH itself, independent of IGF-1, can increase the other ABC transporters including $A b c b 1 a, A b c b 8$, $A b c g 1$ and $A b c g 2$, consistent with the in vitro results (Figure 3A-I). Further analyses revealed a few sex-specific differences in GH/IGF-induced expression of ABC transporters in bGH and GHRKO mice (Figure S5). 

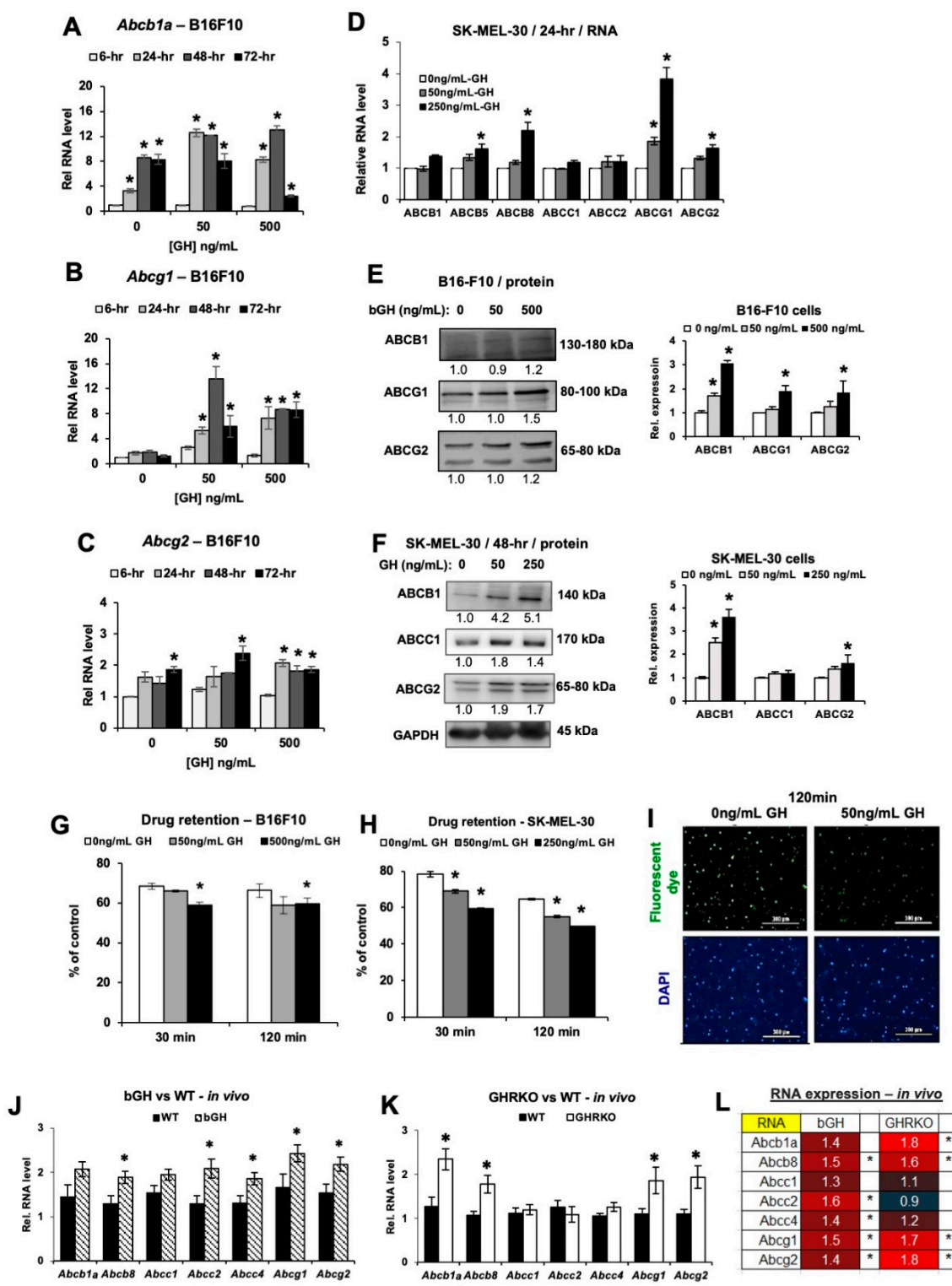

L RNA expression - in vivo

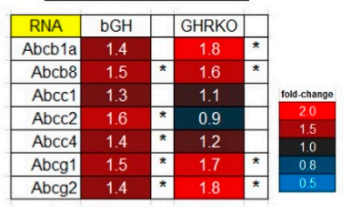

Figure 3. Changes in $\mathrm{ABC}$ efflux pumps in B16-F10 mouse melanoma in vitro and in vivo. (A-C) Changes in RNA levels for Abcb1a, Abcg1, Abcg2 in B16-F10 mouse melanoma cells treated with $\mathrm{bGH}$, normalized against reference genes $(\mathrm{n}=3)$. (D) Changes in RNA levels for several ABC efflux pumps in SK-MEL-30 human melanoma cells treated with hGH for $24 \mathrm{~h}$, normalized against GAPDH gene $(n=3)$. (E) Changes in proteins levels of several ABC efflux pumps of B16-F10 cells treated with bGH for $72 \mathrm{~h}$. Densitometry analysis was performed and normalized to total protein $(\mathrm{n}=3)$. (F) Changes in proteins levels of several ABC efflux pumps of SK-MEL-30 cells treated with hGH for $48 \mathrm{~h}$, normalized to GAPDH $(\mathrm{n}=3)$. (G) Drug retention was decreased in B16-F10 cells pretreated with bGH for 1 week $(n=3)$. $(\mathbf{H})$ Similar results were found in SK-MEL-30 cells $(n=3)$. Data are presented as mean \pm standard deviation $\left({ }^{*}, p<0.05\right.$, Mann-Whitney $\mathrm{U}$ test). (I) Representative images for SK-MEL-30 cells with fluorescent dye (green) treated with and without $50 \mathrm{ng} / \mathrm{mL} \mathrm{hGH}$ for 1 week (20× magnification; scale bar represents $300 \mu \mathrm{m}$ ). (J) Relative RNA levels for seven different ABC efflux pumps in B16-F10 tumors grown in vivo in bGH and WT mice, normalized against reference genes (both sexes combined). bGH mice $(n=12)$, WT mice $(n=12)$. $(\mathbf{K})$ Relative RNA levels for seven different $A B C$ efflux pumps in B16-F10 tumors grown in vivo in GHRKO and WT mice, normalized against reference genes (both sexes combined). GHRKO mice $(n=10)$, WT mice $(n=13)$. (L) Heatmap showing the variations in RNA expression of ABC efflux pumps in tumors in bGH or GHRKO mice (both sexes combined). Data are presented as mean \pm standard error ${ }^{*}, p<0.05$, unpaired student's $t$-test). 
In male bGH mice, $A b c b 1 a(p=0.038)$ and $A b c g 1$ ( $p=0.0001)$ were significantly upregulated (Figure S5A), while in the female bGH mice with significantly higher tumoral IGF-1 production (Figure 2I), five ABC transporters (Abcb8,Abcc1, Abcc2, Abcc4, and Abcg2; $p=0.004,0.015,0.002,0.015$, and 0.009, respectively) were significantly upregulated (Figure $\mathrm{S} 5 \mathrm{~B}$ ). Interestingly, in the GHRKO mice, the males had significantly higher Abcb1a ( $p=0.0001), A b c b 8(p=0.017), A b c g 1(p=0.016)$, and Abcg2 $(p=0.015)$ (Figure S5C), while the females with elevated tumoral GH (Figure $2 \mathrm{H}$ ) had significantly higher Abcg2 ( $p=0.035$ ) but none of the Abcc-type transporters (Figure S5C,D). At the protein level, the ABCB1 expression was confirmed to be significantly upregulated in tumors from male GHRKO mice, indicating a GH specific effect $(p=0.025)$ (Figures S5F and S9). We previously reported that GH-mediated upregulation of ABC-type multidrug efflux pumps is particularly enhanced when the cells are treated with chemotherapeutics like doxorubicin [58]. Here, even at the basal stage (i.e., prior to any drug-exposure), the tumors in bGH and GHRKO mice had markedly higher RNA expression of different groups of ABC-type drug efflux pumps when compared to their WT counterparts (Figure 3L), indicating that GH specifically increases expression of the $A b c b$ and $A b c g$ groups of drug efflux pumps, while IGF-1 increases expression of the $A b c c$ group of drug efflux pumps. We suggest that both $\mathrm{GH}$ and IGF-1 can selectively prime the tumors to be drug resistant.

In this regard, we reviewed and compiled all of the published studies on GH, IGF-1, and both of their effects on ABC transporter expression in different cancers (Table 1). Notably, unlike the current study, none of the earlier studies compared GH vs. IGF-1 effects. Cross comparison of the reported effects of GH and IGF-1 on ABC transporter expression in different cancers (including results from this study) are shown in Table 1 and indicates that IGF-1 has an impact in particularly elevating the $A b c c$ group of $\mathrm{ABC}$ transporters, while $\mathrm{GH}$ elevates the $A b c b$ and $A b c g$ groups.

Table 1. Summary of known effects of GH/IGF-1 axis on ABC transporters in different cancers.

\begin{tabular}{|c|c|c|}
\hline Effects of GH & \multirow{2}{*}{ Observed Effects } & \multirow{2}{*}{ Refs } \\
\hline Cancer Type & & \\
\hline $\begin{array}{l}\text { Breast Cancer } \\
\text { (In vivo) }\end{array}$ & Increased ABCG2 & [71] \\
\hline $\begin{array}{l}\text { Human Melanoma } \\
\text { (In vitro) }\end{array}$ & Increased $\mathrm{ABCB} 1, \mathrm{ABCB} 5, \mathrm{ABCB} 8, \mathrm{ABCC} 1, \mathrm{ABCC} 2, \mathrm{ABCG} 1, \mathrm{ABCG} 2$ & $\begin{array}{c}{[58]} \\
\text { Current study }\end{array}$ \\
\hline $\begin{array}{l}\text { Mouse Melanoma } \\
\text { (In vitro) }\end{array}$ & Increased $A b c b 1 a, A b c g 1, A b c g 2$ & Current study \\
\hline $\begin{array}{l}\text { Mouse Melanoma } \\
\text { (In vivo) }\end{array}$ & Increased $A b c b 1 a, A b c b 8, A b c g 1, A b c g 2$ & Current study \\
\hline Effects of IGF-1 & \multirow{2}{*}{ Observed Effects } & \multirow{2}{*}{ Refs } \\
\hline Cancer Type & & \\
\hline $\begin{array}{l}\text { Ovarian cancer } \\
\text { (In vitro and vivo) }\end{array}$ & Increased $\mathrm{ABCB} 1, \mathrm{ABCC} 1, \mathrm{ABCC} 2, \mathrm{ABCC} 3, \mathrm{ABCC}$, ABCG2 & {$[72,73]$} \\
\hline $\begin{array}{l}\text { Colorectal cancer } \\
\text { (In vitro) }\end{array}$ & Increased $\mathrm{ABCC} 2$ & [74] \\
\hline $\begin{array}{l}\text { Leukemia } \\
\text { (In vitro) }\end{array}$ & $\begin{array}{c}\text { Increased ABCB1, } \mathrm{ABCC} 1, \mathrm{ABCC} 2, \mathrm{ABCC} 3, \\
\mathrm{ABCG} 2\end{array}$ & [75] \\
\hline $\begin{array}{l}\text { Mouse Melanoma } \\
\text { (In vivo) }\end{array}$ & Increased $A b c c 2, A b c c 4$ & Current study \\
\hline
\end{tabular}

Italicized gene names represent RNA in mouse; capitalized gene names represent human RNA or proteins. 


\subsection{Elevated GH Drives Expression of Epithelial-to-Mesenchymal Transition (EMT) Markers In Vitro and In Vivo}

We analyzed the effect of GH action on the expression levels of EMT markers and transcription factors expression both in cell culture as well as in the tumor lysates from bGH vs. WT and GHRKO vs. WT male and female mice. We previously showed that in human melanoma cells in vitro exogenously added GH upregulates markers of EMT while attenuating GHR expression decreases the EMT induction [57]. Here we queried known markers of EMT in both human and mouse melanoma cells treated with GH. After 24-h GH treatment, SK-MEL-30 human melanoma cells showed a modest but significant increase of multiple EMT-related genes including mesenchymal markers ZEB-1, SNAI1, CLDN1 and SNAI2, while the epithelial marker CDH1 was significantly downregulated (Figure 4A). At the protein level, the mesenchymal markers ZEB-1, CDH2 and SNAI2 were all markedly higher following GH treatment in SK-MEL-30 (Figure 4C and Figure S9). In B16-F10 mouse melanoma cells, although a 24-h bGH treatment did not significantly increase the EMT markers (Figure 4B), at the protein level, we saw a significant increase in ZEB-1 (Figure 4D and Figure S9). Since GH does not induce the expression of IGF-1 in cultured B16-F10 cells in vitro (Figure 1A and Figure S1E), the regulation of ZEB-1 expression in cultured cells is possibly a direct effect of GH, independent of IGF-1. An increase in mesenchymal markers indicates an increase in the invasion capacity of the tumor cells. Using a basement membrane invasion assays, we saw that both B16-F10 cells and SK-MEL-30 cells did have a GH dose dependent increase in invasion capacity compared with control cells (Figure 4E,F), which corroborates the known effect of GH in promoting the process of EMT in normal and cancer tissues [76].

An assessment of the GH and IGF-1 effects on EMT in vivo, revealed significant overlap between GH and IGF-1 in driving EMT (Figure 4G,H). In the B16-F10 tumors derived from bGH mice, RNA expression analyses showed significant upregulation of the mesenchymal transcription factors Zeb1 ( $p$ $=0.020)$ and Snai1 $(p=0.035$ ) (Figure $4 G)$, but only similar, non-statistically significant trends in the GHRKO mice (Figure 4H). However, the epithelial marker Cdh1 was significantly suppressed in the GHRKO vs. the WT mice. Several previous studies have reported IGF-1 to be a potent inducer of the EMT process [60]. As shown in the heatmap (Figure S6H), at the RNA level, the trend of EMT marker changes in tumors from bGH and GHRKO mice was similar, implying that GH can directly induce EMT, independent of IGF-1. In vitro IGF-1 treatment alone markedly elevated the RNA levels of Zeb1 (Figure S6E). Sex-specific RNA analyses further showed a marked increase of Zeb1 $(p=0.008)$ and Snai1 $(p=0.010)$ in male bGH mice and of Zeb1 $(p=0.028)$ in the female bGH mice, while male GHRKO mice had elevated Snail compared to the WT controls (Figure S6A-D). We also observed a significant increase in SNAI1 and CDH1 protein levels in bGH mice when compared to controls (Figure 4I), but not in GHRKO mice (Figure 4J). In Table 2, we summarized all previous studies and work presented here on the effects of GH or IGF-1 in EMT induction in various types of cancer in vitro or in vivo. As is readily observable in Table 2, both GH and IGF-1 are potent inducers of EMT, with significant overlap in suppressing epithelial markers and upregulating several mesenchymal factors. 
A

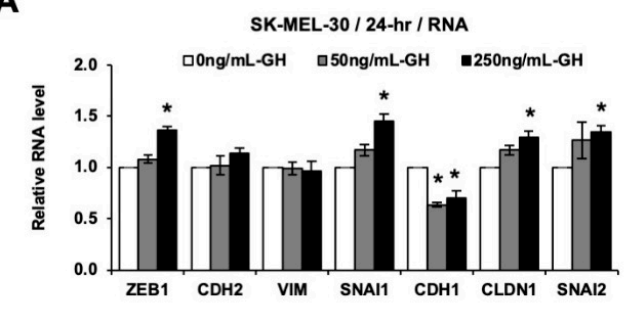

B

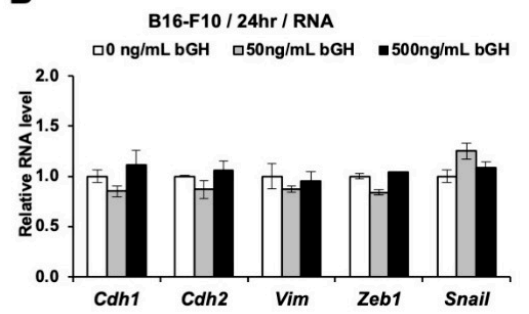

C $\begin{gathered}\text { SK-MEL-30-protein level } \\ \text { GH }(\mathrm{ng} / \mathrm{mL}) \rightarrow 0 \quad 50 \quad 250\end{gathered}$ ZEB1 200 kDa

VIM 57 kDa

$\mathrm{CDH} 2$\begin{tabular}{lll}
$1.0 \quad 2.2 \quad 1.7$ \\
$\square$ & $140 \mathrm{kDa}$ \\
\hline
\end{tabular}

b-CAT $92 \mathrm{kDa}$

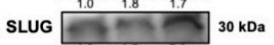

SNAIL

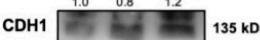

GAPDH $-\square 5 \mathrm{kDa}$

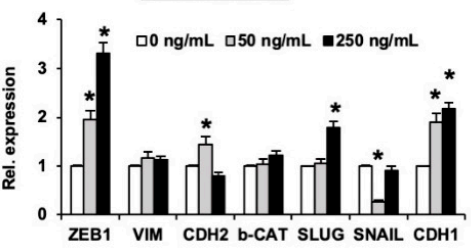

G

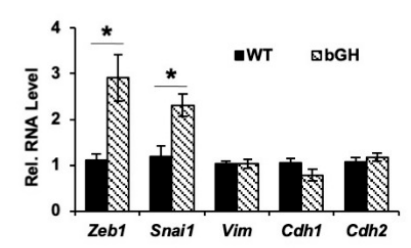

I

घWT घbGH

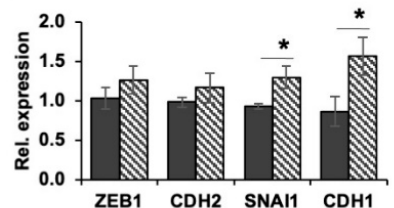
SNAIL
D B16-F10 - protein level E $\mathrm{bGH}(\mathrm{ng} / \mathrm{mL}) \rightarrow 0 \quad 50 \quad 500$ ZEB1 $-\square 200 \mathrm{kDa}$ CDH1 $-235 \mathrm{kDa}$
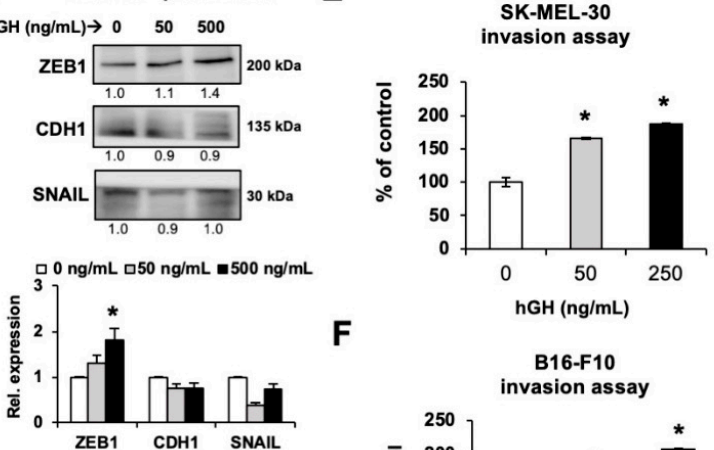

$\mathbf{F}$

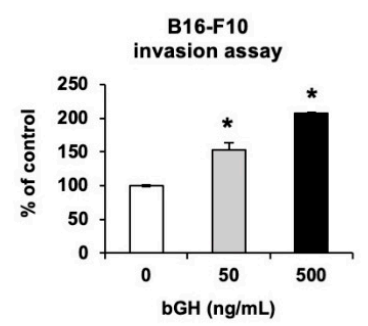

H GHRKo vs WT - RNA - in vivo

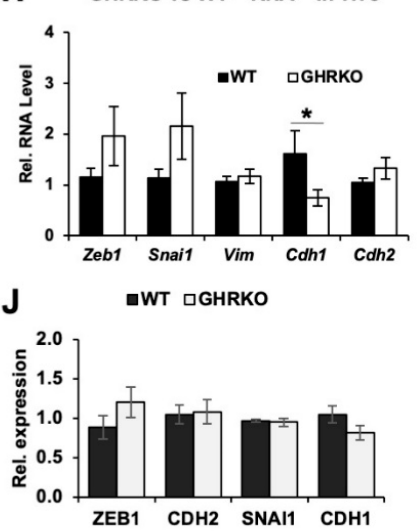

Figure 4. Changes in markers of epithelial-to-mesenchymal transition (EMT) in melanoma in vitro and in vivo. (A) Changes in RNA levels in SK-MEL-30 cells treated with $\mathrm{hGH}$ for $24 \mathrm{~h}$, normalized against GAPDH gene. (B) Relative RNA levels in B16-F10 cells treated with bGH for $24 \mathrm{~h}$, normalized against reference genes. (C) Proteins levels of EMT markers in SK-MEL-30 cells after hGH treatment for $48 \mathrm{~h}$, normalized to GAPDH. (D) Proteins levels of EMT markers in B16-F10 cells after bGH treatment for 72 h, normalized against total protein. (E,F) Invasion of SK-MEL-30 (E) and B16-F10 (F) cells after 7-days $\mathrm{hGH}$ or bGH pretreatment. Fold changes are presented and refer to control. Data are presented as mean \pm standard deviation ( $\mathrm{n}=3 ;{ }^{*}, p<0.05$, Mann-Whitney $\mathrm{U}$ test). $(\mathbf{G}, \mathbf{H})$ Relative RNA levels of EMT markers in B16-F10 tumors grown in vivo in bGH (G) or GHRKO (H) mice, normalized against reference genes (both sexes combined). (I,J) Proteins levels of EMT markers in tumors from WT, bGH (I) or GHRKO (J) mice. Representative images are shown in Figure S6F,G. (both sexes combined; bGH mice $\mathrm{n}=12$, WT mice $\mathrm{n}=12$; GHRKO mice $\mathrm{n}=10$, WT mice $\mathrm{n}=13$ ). Data are presented as mean \pm standard error $(*, p<0.05$, unpaired student's t-test). 
Table 2. Summary of the effects of GH and IGF-1 on EMT mediators in different cancers.

\begin{tabular}{|c|c|c|}
\hline $\begin{array}{l}\text { Effects of GH } \\
\text { Cancer Type }\end{array}$ & Observed Effects & Refs \\
\hline $\begin{array}{c}\text { Breast Cancer } \\
\text { (In vitro and in vivo) }\end{array}$ & $\begin{array}{l}\text { Increased SNAIL, SLUG, VIM, CDH2, FN1 } \\
\text { Decreased CDH1, OCLN, CTNNA1, JUP }\end{array}$ & {$[77,78]$} \\
\hline $\begin{array}{l}\text { Endometrial adenocarcinoma } \\
\text { (In vitro) }\end{array}$ & $\begin{array}{c}\text { Increased FN1 } \\
\text { Decreased CTNNA1 }\end{array}$ & [24] \\
\hline $\begin{array}{l}\text { Colorectal cancer } \\
\text { (In vitro and in vivo) }\end{array}$ & $\begin{array}{l}\text { Increased SNAIL, TWIST2, FN1 } \\
\text { Decreased CDH1, OCLN }\end{array}$ & {$[45,79]$} \\
\hline $\begin{array}{l}\text { Pancreatic ductal adenocarcinoma } \\
\text { (In vitro) }\end{array}$ & $\begin{array}{c}\text { Increased SNAIL, SLUG, VIM, ZEB1, CDH2, } \\
\text { CTNNB2 } \\
\text { Decreased CDH1 }\end{array}$ & [21] \\
\hline $\begin{array}{l}\text { Human Melanoma } \\
\text { (In vitro) }\end{array}$ & $\begin{array}{c}\text { Increased SNAIL, SLUG, VIM, ZEB1, CDH2, CLDN1 } \\
\text { Decreased CDH1 }\end{array}$ & $\begin{array}{l}{[57]} \\
\text { Current study }\end{array}$ \\
\hline $\begin{array}{l}\text { Mouse Melanoma } \\
\quad \text { (In vivo) }\end{array}$ & $\begin{array}{l}\text { Increased Zeb1, Snai1 } \\
\text { Decreased Cdh1 }\end{array}$ & Current study \\
\hline $\begin{array}{c}\text { Effects of IGF-1 } \\
\text { Cancer Type }\end{array}$ & Observed Effects & Refs \\
\hline $\begin{array}{c}\text { Breast Cancer } \\
\text { (In vitro and in vivo) }\end{array}$ & $\begin{array}{c}\text { Increased SNAIL, VIM, ZEB1, CDH2, TWIST1, FN1 } \\
\text { Decreased CDH1, OCLN }\end{array}$ & {$[80,81]$} \\
\hline $\begin{array}{l}\text { Colorectal cancer } \\
\text { (In vitro and in vivo) }\end{array}$ & $\begin{array}{l}\text { Increased SNAIL, VIM, CDH2 } \\
\text { Decreased CDH1, ZO-1 }\end{array}$ & {$[82,83]$} \\
\hline $\begin{array}{l}\text { Lung cancer } \\
\text { (In vitro) }\end{array}$ & $\begin{array}{c}\text { Increased SNAIL, VIM, CDH2, FN1, CTNNB1 } \\
\text { Decreased CDH1 }\end{array}$ & {$[84,85]$} \\
\hline $\begin{array}{l}\text { Gastric cancer } \\
\text { (In vitro) }\end{array}$ & Increased SNAIL, ZEB2, CDH2 & [86-88] \\
\hline $\begin{array}{l}\text { Prostate cancer } \\
\quad \text { (In vitro) }\end{array}$ & $\begin{array}{c}\text { Increased ZEB1, VIM, CDH2, FN1, CTNNB1 } \\
\text { Decreased CDH1 }\end{array}$ & {$[89,90]$} \\
\hline $\begin{array}{l}\text { Liver cancer } \\
\text { (In vitro) }\end{array}$ & $\begin{array}{c}\text { Increased SNAIL, VIM, CDH2 } \\
\text { Decreased CDH1 }\end{array}$ & [91] \\
\hline $\begin{array}{l}\text { Glioblastoma } \\
\text { (In vitro) }\end{array}$ & $\begin{array}{l}\text { Increased VIM, CDH2 } \\
\text { Decreased CDH1, ZO-1 }\end{array}$ & [92] \\
\hline $\begin{array}{l}\text { Human Melanoma } \\
\text { (In vitro) }\end{array}$ & $\begin{array}{c}\text { Increased ZEB1, CDH2 } \\
\text { Decreased CDH1 }\end{array}$ & {$[60]$} \\
\hline $\begin{array}{l}\text { Mouse Melanoma } \\
\text { (In vitro) }\end{array}$ & Increased Zeb1 & Current study \\
\hline $\begin{array}{l}\text { Mouse Melanoma } \\
\text { (In vivo) }\end{array}$ & $\begin{array}{l}\text { Increased Snai1, Zeb1 } \\
\text { Decreased Cdh1 (m) }\end{array}$ & Current study \\
\hline
\end{tabular}

Italicized gene names represent RNA in mouse; capitalized gene names represent human RNA or proteins. $(\mathrm{m})$ indicates males only.

\section{Discussion}

GHR expression is elevated in a wide range of cancers $[8,17-19,21]$, especially in the case of melanoma [56], implicating the potential involvement of GH in this process. Previously, we had reported that not only do melanoma cells overexpress GHR but also that targeting GHR in human melanoma cells attenuates tumor progression, EMT induction, drug efflux and more importantly, sensitizes these cells to chemotherapy in vitro $[57,58]$. Additionally, enhanced metastasis of mouse melanoma cells to the lungs in response to locally elevated GH levels in DJ-1 knockout mice was recently reported and confirms a role of GHR in melanoma metastases [4]. Our current study 
provides a first in vivo validation to our earlier in vitro mechanistic observations on the role of GH in melanoma chemoresistance.

Locally produced GH and IGF-1 in the tumor microenvironment imparts autocrine and paracrine effects to drive tumor growth in multiple ways [49]. A series of studies by Lobie et al. have highlighted that autocrine $\mathrm{GH}$ is potent in mediating $\mathrm{GH}$ action comparative to endocrine $\mathrm{GH}$, in breast cancer $[11,47,48,51-54,77]$. Due to the complexity of the endocrine features of the GH/IGF-1 axis, it is difficult to distinguish between the direct effects of GH and its indirect effects via IGF-1. Mouse B16-F10 cells are compatible with the C57BL/6J mice with high-GH-high-IGF-1 (bGH mice) and high-GH-low-IGF-1 (GHRKO mice) in vivo, and allowed a distinctive opportunity to tease out specific effects of GH or IGF-1 [54].

Recently, we reported that knocking down the GHR attenuated both ABC-type multidrug efflux pump gene expression and markers of EMT in multiple human melanoma cell lines, thereby improving drug efficacy $[57,58]$. In melanoma, the activation of the EMT strongly correlates with not only a transition to aggressive metastases [60,93], but also with an upregulation of mechanisms of drug resistance $[58,94]$. Our observations in this report, using a syngeneic mouse model of melanoma, corroborated existing reports of GH/IGF effects in human melanoma cells (Tables 1 and 2). EMT appeared to be driven by both GH and IGF-1 (Figure 4 and Table 2). However, we observed that GH or IGF-1 independently affect different groups of ABC-type multidrug efflux pump expression in our mouse models (Figure 3 and Table 1). A significant upregulation of markers of EMT mediators as well as $A B C$ drug efflux pumps, even in the absence of any drug mediated induction in this study, suggests a critical role of $\mathrm{GH}$ in establishing an intrinsic therapy resistance in melanoma. The RNA levels of $A b c b 1 a, A b c g 1$ and $A b c g 2$, some of the most studied drug transporters in cancer, were elevated in bGH and GHRKO mice, both of which have elevated circulating GH irrespective of the levels of IGF-1. Besides the endocrine GH and IGF-1 levels, the tumoral production of GH and IGF-1 in vivo as depicted in Figure 2G-J is of importance. Together, the results strongly suggest that GH has a direct effect in upregulating $A b c b 1 a, A b c b 8, A b c g 1$, and $A b c g 2$ expression independent of IGF-1 in vivo (Table 1). The intense drug resistance which is the hallmark feature of aggressive forms of melanoma could thus be a function of GH action. We also identified that IGF-1 appears to particularly upregulate the $A b c c$ subtype transporters in contrast to a direct GH effect (Figure 3 and Table 1). Indeed, previous studies showed that suppression of IGF-1R decreases ABCC2 expression and promoted drug sensitivity in human colon cancer cells [74], and that IGF-1 increased the expression of ABCC1, ABCC2, and ABCC3 in both leukemia cells and ovarian cancer cells $[73,75]$. This study is the first to compare the different effects of GH and IGF-1 in melanoma in vivo. It is important to note that GH has IGF-1-independent effects in upregulating subgroups of $A B C$ transporters (Table 1). Recently a GH induced chemoresistance by upregulation of ABCG2 has been recently validated in breast cancer as well [71].

Recently, Caramel et al. [95] had shown that a switch from a Zeb2-dominant phenotype to an EMT-inducing Zeb1-dominant phenotype is a driver of malignancy in melanoma. Furthermore, Zeb1 has also been identified as a critical oncogenic regulator in uveal melanoma [96]. It has been shown that downregulation of IGF-1 decreased levels of ZEB1 and CDH2/N-cadherin associated with increased levels of CDH1/E-cadherin and MITF, the major regulator of melanocyte differentiation [60]. In our study, we confirmed a marked and consistent increase in levels of GH-induced Zeb1 in vivo, under both conditions of elevated GH (in bGH and GHRKO mice) as summarized in Table 2. These data along with our observations of elevated Snai1/Snail and reduced Cdh1/E-cadherin in this syngeneic mouse model additionally point to a role of GH in driving lineage plasticity or phenotypic switch in cancer cells [76]. As shown in Table 2, GH and IGF-1 have been separately shown to induce EMT in various types of cancers both in vitro and in vivo, including breast, lung, colon, and glioblastoma. Our results suggest that both GH and IGF-1 can induce EMT, while IGF-1 is perhaps more potent.

An interesting finding of our study were sex-specific differences between the patterns of altered expression of ABC-type multidrug efflux pumps and EMT markers in male and female mice with elevated $\mathrm{GH}-\mathrm{a}$ critical area of focus in the development of more personalized therapies. The role of 
estrogen, differences in the pattern of GH release between male and female mice, and a putative role of a differential IGF axis could be potential confounding factors in choice of therapy. Also, GH exerts several sexually dimorphic gene expressions in several tissues [97,98].

Despite changes in tumor gene expression and increased cell growth in response to GH treatment in vitro, we did not observe increased tumor growth or size due to excess GH or IGF-1 in vivo. There could be several possible reasons for this observation. First, the endogenous GH/IGF levels in WT mice could be adequate to drive tumor growth and may mask the effects of supraphysiological levels of GH or IGF-1. Additionally, tumoral production of GH and IGF-1 poses another compounding factor in this problem. This could be addressed in the future with smaller tumor inoculum in the mice. However, in relevance to our observations of melanoma tumor growth in the mouse models of high-GH-high-IGF-1 (bGH mice) and high-GH-low-IGF-1 (GHRKO mice), we further analyzed melanoma patient data from the human TCGA database using the GEPIA platform [99]. To assess the effects of GH responsivity in determining survival among melanoma patients with high and low GHR expression, we compared survival between melanoma patients within the top and bottom quartiles for GHR expression level. We observed no significant differences in either overall or disease-free survivals in the Kaplan-Meier plots between these two patient groups. To assess effects of IGF-1 responsivity in determining patient survival, we conducted a similar comparison between melanoma patients within the top and bottom quartiles for IGF-1R expression levels and obtained similar results. This indicates that neither GHR nor IGF-1R expression appears to be a determinant of overall mortality in melanoma patients in the TCGA cohort (Figure S7), though they may influence treatment response and outcome, as the expression of several EMT mediators and ABC transporters were upregulated in the TCGA dataset irrespective of the heterogeneity in treatment patterns (Figure S8). A controlled study with combination of drug doses and GHR antagonists or GH treatment in vivo could validate the theory. Lastly, in this regard it is worthwhile to refer to a hallmark report from Green et al. in 1985, where they presented a dual-effector theory of GH action [100]—stating that GH drives cellular differentiation while IGF-1 drives the clonal expansion. Thus, homeostatic interactions between GH and IGF-1 and subsequent net effects in cancer is unexplored despite being very provocative towards explaining oncogenic processes like EMT, drug efflux, apoptosis, cancer stemness, and metastases where GH and IGF-1 overlap.

Two independent laboratories have reported that congenital GH insensitivity, as found in patients with Laron Syndrome (LS), imparts a dramatic resistance to cancer in humans [101,102]. This is corroborated by the high degree of cancer resistance in GHRKO, or "Laron mice", and other GH deficient dwarf mouse models [1,14,16]. Additionally, scores of in vitro, in vivo, epidemiological and clinical studies have validated the 'oncodriver' role of GH-GHR interaction in several human cancers $[39,103]$. Within the normal population, the potential anti-cancer effects of suppressing the GH-axis are still underappreciated. Numerous scientific studies have now shown that GH drives progression of breast and endometrial [3,9,11,15,24,25,46-54], colorectal [18,19], thyroid [22], and hepatocellular carcinoma [23]. GHR inhibition, using the GHR antagonist, Pegvisomant, alone has been found to attenuate the growth of both colon and breast cancers [10,104]. Additionally, recent research has strongly implicated GH action in driving cancer therapy resistance [40]. It is important to note that recombinant hGH replacement therapy in GH deficient patients with no prior report of cancer, has been found safe, and is not associated with any significant increases in cancer risk [6,105-110]. On the other hand, the role of IGF-1 in stimulating tumor progression is well established, as numerous studies have shown that elevated, and even basal IGF-1 levels are strongly associated with detrimental cancer prognosis and therapy resistance [105,106,111-114]. Decreased IGF-1 levels reduce rates of malignancy $[115,116]$ and the inhibition of IGF-1R inhibits cancer growth $[60,117]$. Accordingly, several IGF-1R inhibitors have reached different stages of anti-cancer clinical development; yet none have been approved for clinical application due to complications like hyperglycemia and hyperinsulinemia [118]. Therefore, GHR inhibition appears to be a safer and validated point of intervention to suppress cancer growth and especially drug resistance, as well as in reducing circulating IGF-1 levels and improving insulin sensitivity [63,119-121]. Here, we confirmed that both GH and IGF-1 have independent as well 
as overlapping actions in the intrinsic therapy refractoriness of melanoma. To our knowledge this is the first in vivo report of the tumor-promoting mechanisms of GH and IGF-1 in melanoma.

\section{Materials and Methods}

\subsection{Cell Culture and GH}

B16-F10 mouse melanoma cells (CRL-6475, ATCC, Manassas, VA, USA) and mouse L cell fibroblast (CRL-2648, ATCC) were purchased from ATCC. SK-MEL-30 human melanoma cells (CSC-C0302, Creative Bioarray, Shirley, NY, USA) were purchased from Creative Bioarray. The cells were maintained in high glucose DMEM or EMEM, with 10\% FBS (complete growth media) and $1 \times$ penicillin-streptomycin. Cells were passaged twice a week (passage numbers are $<20$ ). Recombinant bovine GH (\#CYT-636, ProspecBio, East Brunswick, NJ, USA) was used in B16-F10 cells; recombinant human GH (\#ABIN9344914, Antibodies Online, Limerick, PA, USA) was used in SK-MEL-30 cells. Following preliminary GH dose-response studies spanning several orders of magnitude (5, 50, and 500 $\mathrm{ng} / \mathrm{mL}$ ), the $500 \mathrm{ng} / \mathrm{mL}$ dose of bGH elicited the greatest response and was thus selected for further experiments using the B16-F10 mouse cell line. The doses of hGH used in SK-MEL-30 cells were 50 and $250 \mathrm{ng} / \mathrm{mL}$. For short-term GH signaling studies, B16-F10 or SK-MEL-30 cells were seeded on 6-well plates and incubated overnight in complete growth media. On the second day, the media was replaced with serum-free media for $4 \mathrm{~h}$ prior to the treatment of bGH or hGH as indicated. In longer-term treatment $(24,48$ or $72 \mathrm{~h}$ ), cells were incubated with bGH or hGH in $2 \%$ FBS media, as previously described [57-59].

\subsection{Real-Time RT-qPCR}

Total RNA from cells and tumor tissues was isolated (GeneJET RNA Purification kit, \#K0732 Thermo Fisher Scientific, Waltham, MA, USA), quantified using the BioAnalyzer 2100 (Agilent, Santa Clara, CA, USA), and reverse transcribed to cDNA (Thermo Fisher Scientific Maxima Enzyme Mix, \#K1642, 5× Reaction Mix, \#R1362) as previously described [122]. Maxima SYBR Green/Fluorescein qPCR Master Mix (Thermo Fisher Scientific, \#K0243) was employed to quantitatively measure the abundances of target RNA in the samples using an iCycler (BioRad, Hercules, CA, USA). Qbase was used for data analysis. The net RNA levels of $G h, G h r$, Igf1 and $I g f-1 r$ are presented in $2^{\wedge}(-\mathrm{dCt})$ format. Relative RNA levels are presented in $2^{\wedge}(-\mathrm{ddC})$ format and normalized against reference genes (Gapdh, B2m, Eif3f or Hprt). Fold changes are shown in relative to controls. The primer sequences are listed in Table S1.

\subsection{Immunocytochemistry}

Cells were seeded at 10,000 cells $/ \mathrm{cm}^{2}$ in 8 -well chamber slides and fixed with $4 \%$ freshly-prepared formaldehyde ( $\mathrm{pH}$ 6.9) for $15 \mathrm{~min}$ at room temperature (RT) as previously done [58]. After fixation, the cells were permeabilized with $0.2 \%$ Triton-X100 in phosphate buffered saline (PBS) for 15 min at RT, followed by blocking with 1\% BSA, glycine and $0.1 \%$ Tween-20 in PBS for $2 \mathrm{~h}$ at RT. Then cells were incubated with primary antibody at 1:250 dilution at $4{ }^{\circ} \mathrm{C}$ for $12 \mathrm{~h}$, washed four times with 0.1\% Tween-20 containing PBS (PBST) and incubated with secondary antibody (1:1000 dilution) at RT for $1 \mathrm{~h}$. Finally, the slides were washed four times with PBST and the samples were mounted with DAPI-containing Fluoroshield mounting medium (\#ab104139, Abcam, Cambridge, UK). Rabbit anti-human GHR monoclonal antibody (Abcam \#ab134078) and goat anti-rabbit secondary antibody with AlexaFluor488 tag (\#R37116, Life Technologies, Carlsbad, CA, USA) were used. Microscopic imaging was done using Cytation 3 imaging reader (BioTek, Winooski, VT, USA) and Gen5 2.09 software. The scale bar represents $100 \mu \mathrm{m}$. Magnification was at $20 \times$. 


\subsection{Knockdown of GHR Expression by siRNA}

B16-F10 mouse melanoma cells were transfected with small interfering (si) RNA (GHR siRNA: \#4390771, \#4390771, Thermo Fisher Scientific; \#NM_010284, Sigma Aldrich, St. Louis, MO, USA) targeting the GHR gene using Lipofectamine RNAi MAX Transfection Reagent (Thermo Fisher Scientific, \#13778075). Control cells were transfected with scrambled control siRNA (Thermo Fisher Scientific, Scramble siRNA: \#4390843). Efficiency of GHR RNA knockdown was verified by real-time RT-qPCR and confirmed via western blotting for GH-induced tyrosine phosphorylated STAT5 (CST \#9351). Following the knockdown of GHR in the cell line, proliferation assays were performed to test the effect of GH on cell growth. The GHR of human SK-MEL-30 cells were knocked down similarly using pre-designed GHR-targeting siRNA from Origene (Rockville, MD, USA) and verified by real-time RT-qPCR. A universal scrambled siRNA duplex (Origene \#SR30004) was used as control.

\subsection{Western Blotting}

Protein extracted from B16-F10 and SK-MEL-30 cells treated with or without GH, and tumors was tested for the phosphorylation of STAT5, ERK1/2, AKT, SRC, CDH1, CDH2, ZEB1, SNAI2, SNAIL/SNAI1, VIM, b-CAT, t-ERK1/2, t-AKT, ABCC1, ABCB1, ABCG2, IGF1R beta, p-STAT1, t-STAT1, p-STAT3, t-STAT3, t-STAT5 (CST \#9351, \#4370, \#4058, \#2101, \#3195, \#13116, \#3396, \#9585, \#3879, \#2101, \#5741, \#8480, \#9102, \#4685, \#72202, \#13342, \#42078, \#3027, \#9167, \#14994, \#9145, \#12640, \#94205), and ABCG1 (NB400-132, Novus Biologicals, Littleton, CO, USA) to determine their activation or expression induced by GH as previously described [123]. $\beta$-Actin, GAPDH (\#4970, \#5174, CST, Danvers, MA, USA) or total protein staining (\#926-11011, LI-COR, Lincoln, NE, USA) were used as loading controls. Densitometry analysis of individual blots was performed using Image Studio LITE Ver 5.2 (LI-COR, Lincoln, NE, USA). The relative expression levels (fold change relative to controls) are labeled under each band of representative images.

\subsection{Cell Proliferation Assay}

Approximately ten thousand B16-F10 or SK-MEL-30 cells were seeded on 96-well plates and incubated overnight in complete growth media. On the second day, the media was replaced with serum-free media for $4 \mathrm{~h}$. Cells were incubated for an additional $48 \mathrm{~h}$ in $2 \%$ FBS media with various doses of bGH or hGH. Cell proliferation was determined using a Resazurin Cell Viability Assay (Sigma Aldrich) [124]. For cell proliferation assays in the presence of siRNA, approximately 5000 cells were seeded per well and transfected with siRNA in complete growth media. After $48 \mathrm{~h}$, the cells were washed and treated with $500 \mathrm{ng} / \mathrm{mL}$ bGH or 50 and $250 \mathrm{ng} / \mathrm{mL} \mathrm{hGH}$ in $2 \%$ FBS for $48 \mathrm{~h}$. At the end of this assay, cell viability was determined.

\subsection{Cellular Metabolism}

Extracellular acidification rate (ECAR) and oxygen consumption rate (OCR) of the cells or tumor tissues were measured using a Seahorse XFe24 Analyzer (Agilent). The cells were seeded in 24-well plates overnight and incubated with serum-free media for $4 \mathrm{~h}$ followed by a 24 -h incubation in serum-free media containing bGH. The ECAR and OCR of the cells were then analyzed using a Glycolysis Stress Test and Mito Stress Test (Agilent) as previously described [125]. Tumor tissues collected at dissection were sliced and weighed before their basal levels of ECAR and OCR were measured in Seahorse assay media (102365-100, Agilent). The measurements were normalized to the weight of each sample.

\subsection{Mouse Models of Subcutaneous Melanoma}

12-week-old male and female GHRKO and bGH mice, as well as their respective WT controls, all in a C57BL/6J genetic background were used $[37,38,126]$. These syngeneic mice are widely used for the evaluation of B16-F10 melanoma cells injected subcutaneously in vivo [127]. In this study, 5 
million cells were subcutaneously inoculated into the flank of each mouse. The GHRKO and bGH mice were housed with their WT littermate controls. The lengths of perpendicular tumor diameters were measured every other day using a digital caliper as previously described [126]. Tumor volume was calculated using the formula: tumor size $=0.5 \times($ length $) \times(\text { breadth })^{2}$ [126]. Male bGH $(\mathrm{n}=5), \mathrm{WT}$ mice $(\mathrm{n}=6)$; female bGH $(\mathrm{n}=7)$, WT mice $(\mathrm{n}=6)$; male GHRKO $(\mathrm{n}=6)$, WT $(\mathrm{n}=8)$; female GHRKO $(\mathrm{n}=4)$, WT $(\mathrm{n}=5)$. After the mice were sacrificed, tumors were surgically removed, weighed, frozen in liquid nitrogen and stored at $-80^{\circ} \mathrm{C}$ until RNA and protein was extracted and analyzed. Animal studies were performed in accordance to policies of the Ohio University Institutional Animal Care and Use Committee and fully complied with all federal, state and local policies $(16-\mathrm{H}-016)$.

\subsection{Enzyme-Linked Immunosorbent Assay (ELISA)}

To detect released IGF-1 levels in supernatants from cultured cells, B16-F10 cells were seeded on 12-well plates and incubated overnight in complete growth media. On the second day, the media was removed, and cells were rinsed with PBS twice. Then cells were incubated with various doses of bGH in serum-free media for 24 or $48 \mathrm{~h}$. Afterward, supernatants of cultured cells were collected and measured by ELISA for IGF-1 (\#22-IG1MS-E01, ALPCO, Salem, NH, USA). For tumor GH and IGF-1 measurements, lysed tumor proteins were collected and quantified by Bradford assay. GH and IGF-1 were quantified by ELISA kits (\#22-GHOMS-E01; \#22-IG1MS-E01, ALPCO) and normalized to total protein concentrations.

\subsection{Drug Retention Assay}

B16-F10 or SK-MEL-30 cells were pretreated with GH in 2\% FBS-containing DMEM or EMEM for a week, the media being freshly prepared and replaced every other day. On the assay day, cells were trypsinized, counted and suspended at 1 million cells per $\mathrm{mL}$ in cold $\mathrm{DiOC}_{2}(3)$ dye on ice for $15 \mathrm{~min}$ (\#ECM910, Chemicon International, Thermo Fisher Scientific). The cells were then centrifuged, and the supernatant removed. The cell pellets were then subsequently resuspended in cold efflux buffer and distributed into different Eppendorf tubes under the following conditions: one set of tubes was kept on ice to deactivate the drug-efflux pumps as controls, while the other two sets were kept in a $37^{\circ} \mathrm{C}$ water bath for $30 \mathrm{~min}$ and $120 \mathrm{~min}$, respectively, allowing the active drug-efflux pumps to drive out the $\mathrm{DiOC}_{2}(3)$ dye. Afterward, the cells were centrifuged and washed. Cell suspensions were dispensed into the wells of a black-wall-clear-bottom 96-well plate and measured in a fluorescence plate reader at an excitation wavelength of $485 \mathrm{~nm}$ and an emission wavelength of $530 \mathrm{~nm}$.

\subsection{Invasion Assay}

B16-F10 or SK-MEL-30 cells were pretreated with GH in 2\% FBS-containing DMEM or EMEM for one week. The media was freshly prepared and changed every other day. On the day of the invasion assay, the cells were trypsinized and counted. One hundred thousand cells were then seeded per well in the upper chamber of the CytoSelect 96-well Cell Invasion Assay kit (CBA-112, Cell Biolabs, Inc., San Diego, CA, USA) and incubated with GH in serum-free media for $24 \mathrm{~h}$. The cells from the underside of the membranes were then dislodged, lysed and stained with CyQuant GR dye solution. The fluorescence for each well at 480/520 nm, which correlates with cell number, was determined using a fluorescence plate reader.

\subsection{Statistics}

All in vitro experiments were repeated at least thrice. For in vitro experiments, we performed normality test, test of homogeneity of variance, followed by the Mann-Whitney U test using the RStudio v4.0.1 software (RStudio, Boston, MA, USA). For in vivo experiments, we performed normality test, test of homogeneity of variance, followed by the unpaired student's t-test. Tumor sizes were analyzed by repeated measures (SPSS Statistics 17.0, Chicago, IL, USA). Significance was set as a $p$ value $\leq 0.05$. 


\section{Conclusions}

In summary, the current study utilized unique syngeneic murine melanoma models of altered GH/IGF expression and represents the first study of the effects of GH on melanoma in vivo. While elevated GH did not accelerate growth of implanted melanoma tumors in vivo, cellular analyses showed that elevated GH activates oncogenic signaling, upregulates the intrinsic capacity of the tumor for drug clearance and metastatic features (Figure 5). The current study is the first to suggest that IGF-1 has a role in specifically elevating the Abcc group of $\mathrm{ABC}$ transporters, while GH specifically elevates Abcb and Abcg type ABC-transporters in melanoma in vivo. Also, both GH and IGF-1 are potent inducers of EMT with significant overlap in suppressing multiple epithelial markers and upregulating several mesenchymal factors. We believe that this study strengthens the foundations of GH-driven drug resistance and warrants future studies in combining GHR antagonism with chemotherapy in treating melanoma.

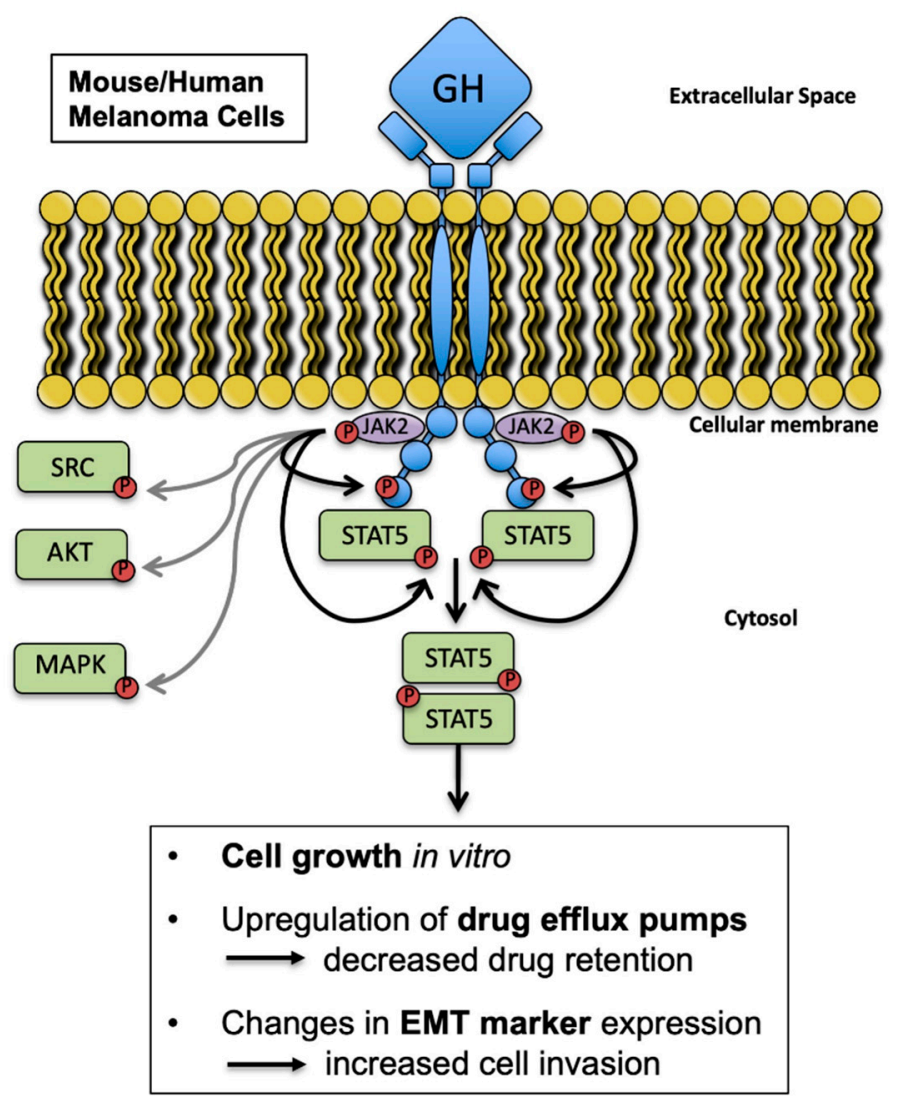

Figure 5. Proposed model for this study. GH stimulates melanoma growth in vitro through GHR activation independent of IGF-1. In the syngeneic mouse melanoma models, elevated GH, independent of IGF-1, alters tumor expression of multidrug efflux pumps and epithelial-mesenchymal transition markers in vivo. 
Supplementary Materials: The following are available online at http://www.mdpi.com/2072-6694/12/12/3640/s1. Figure S1: Melanoma cells are responsive to GH treatment in vitro. Figure S2: Relative RNA expression of Ghr, $I g f-1$, and Igf- $1 r$ in B16-F10 mouse melanoma tumors from bGH and GHRKO mice. Figure S3: GH does not alter the metabolism of either mouse melanoma cells treated with GH for 24 hours or mouse melanoma tumors in bGH and GHRKO mice. Figure S4: Genotypic changes in ABC efflux pump expression in B16-F10 mouse melanoma in vitro. Figure S5: Genotypic changes in ABC efflux pump expression in B16-F10 mouse melanoma tumors in vivo. Figure S6: Genotypic changes in markers of epithelial-to-mesenchymal transition (EMT) in B16-F10 mouse melanoma in vivo. Figure S7: Kaplan-Meier plots for overall and disease-free survivals in human melanoma patients (TCGA dataset). Figure S8: Levels of fold-change in EMT mediators and ABC transporters in human melanoma patients (TCGA dataset). Figure S9: Original images for Western blotting. Table S1: Primer sequences for real-time RT-qPCR and siRNA sequences for mouse and human genes. Table S2: Tumor weight and organs from bGH transgenic and WT C57BL/6 J mice at dissection. Table S3: Tumor weight and organs from GHRKO and WT C57BL/6J mice at dissection.

Author Contributions: Conceptualization, Y.Q., R.B., E.O.L. and J.J.K.; methodology, Y.Q., R.B., S.C.M., N.A.A., S.D.-O., K.R.F., A.L.B., P.K., J.C.T., E.D., J.T.S., and B.E.H.; software, R.B., S.D.-O., and Y.Q.; validation, S.C.M., N.A.A., Y.Q., P.K., and R.B.; investigation, Y.Q., R.B., S.C.M., N.A.A., S.D.-O., P.K., J.C.T., E.D., J.T.S. and D.E.B.; resources, J.J.K.; data curation, R.B., Y.Q.; writing-original draft preparation, Y.Q., R.B., E.O.L. and J.J.K.; writing—review and editing, Y.Q., R.B., S.C.M., N.A.A., S.D.-O., K.R.F., A.L.B., P.K., J.C.T., E.D., J.T.S, B.E.H., E.O.L., D.E.B. and J.J.K.; supervision, J.J.K.; project administration, J.J.K.; funding acquisition, J.J.K., Y.Q. and N.A.A. All authors have read and agreed to the published version of the manuscript.

Funding: This work was supported by the State of Ohio's Eminent Scholar Program that includes a gift from Milton and Lawrence Goll to J.J.K., NIH-R01AG059779, the AMVETS, Edison Biotechnology Institute and Diabetes Institute at Ohio University, Ohio University Research Council funding to Y.Q., and the Provost Undergraduate Research Fund and the John J. Kopchick Molecular Cell Biology/Translational Biomedical Sciences Undergraduate Student Support Fund to N.A.A.

Acknowledgments: We acknowledge Isaac Mendez-Gibson, Cole D. Smith, Colin P. Kruse, Todd McHugh, Jonathan A. Young, Mathew Buchman, Elizabeth A. Jensen, Stephen R. C. Bell, and Savanna F. Lyda, for their assistances and technical support to the experiments and, Christoffer Søndergaard for providing mouse IGF-1. We also acknowledge Edison Biotechnology Institute, Heritage College of Osteopathic Medicine, Molecular Cellular Biology Program and Faculty Research Support Program from Ohio University for financial support for the publication cost.

Conflicts of Interest: The authors declare no conflict of interest.

\section{References}

1. Ikeno, Y.; Hubbard, G.B.; Lee, S.; Cortez, L.A.; Lew, C.M.; Webb, C.R.; Berryman, D.E.; List, E.O.; Kopchick, J.J.; Bartke, A. Reduced incidence and delayed occurrence of fatal neoplastic diseases in growth hormone receptor/binding protein knockout mice. J. Gerontol. A Biol. Sci. Med. Sci. 2009, 64, 522-529. [CrossRef] [PubMed]

2. Pollak, M.; Blouin, M.J.; Zhang, J.C.; Kopchick, J.J. Reduced mammary gland carcinogenesis in transgenic mice expressing a growth hormone antagonist. Br. J. Cancer 2001, 85, 428-430. [CrossRef] [PubMed]

3. Conway-Campbell, B.L.; Wooh, J.W.; Brooks, A.J.; Gordon, D.; Brown, R.J.; Lichanska, A.M.; Chin, H.S.; Barton, C.L.; Boyle, G.M.; Parsons, P.G.; et al. Nuclear targeting of the growth hormone receptor results in dysregulation of cell proliferation and tumorigenesis. Proc. Natl. Acad. Sci. USA 2007, 104, 13331-13336. [CrossRef] [PubMed]

4. Chien, C.H.; Lee, M.J.; Liou, H.C.; Liou, H.H.; Fu, W.M. Growth hormone is increased in the lungs and enhances experimental lung metastasis of melanoma in DJ-1 KO mice. BMC Cancer 2016, 16. [CrossRef]

5. Van der Lely, A.J.; Muller, A.; Janssen, J.A.; Davis, R.J.; Zib, K.A.; Scarlett, J.A.; Lamberts, S.W. Control of tumor size and disease activity during cotreatment with octreotide and the growth hormone receptor antagonist pegvisomant in an acromegalic patient. J. Clin. Endocrinol. Metab. 2001, 86, 478-481. [CrossRef]

6. Boguszewski, C.L.; Boguszewski, M. Growth Hormone's Links to Cancer. Endocr. Rev. 2019, 40, 558-574. [CrossRef]

7. Boguszewski, C.L.; Boguszewski, M.C.; Kopchick, J.J. Growth hormone, insulin-like growth factor system and carcinogenesis. Endokrynol. Pol. 2016, 67, 414-426. [CrossRef]

8. Gebre-Medhin, M.; Kindblom, L.G.; Wennbo, H.; Tornell, J.; Meis-Kindblom, J.M. Growth hormone receptor is expressed in human breast cancer. Am. J. Pathol. 2001, 158, 1217-1222. [CrossRef] 
9. Felice, D.L.; El-Shennawy, L.; Zhao, S.; Lantvit, D.L.; Shen, Q.; Unterman, T.G.; Swanson, S.M.; Frasor, J. Growth hormone potentiates 17beta-estradiol-dependent breast cancer cell proliferation independently of IGF-I receptor signaling. Endocrinology 2013, 154, 3219-3227. [CrossRef]

10. Minoia, M.; Gentilin, E.; Mole, D.; Rossi, M.; Filieri, C.; Tagliati, F.; Baroni, A.; Ambrosio, M.R.; degli Uberti, E.; Zatelli, M.C. Growth hormone receptor blockade inhibits growth hormone-induced chemoresistance by restoring cytotoxic-induced apoptosis in breast cancer cells independently of estrogen receptor expression. J. Clin. Endocrinol. Metab. 2012, 97, E907-E916. [CrossRef]

11. Chen, Y.J.; Zhang, X.; Wu, Z.S.; Wang, J.J.; Lau, A.Y.; Zhu, T.; Lobie, P.E. Autocrine human growth hormone stimulates the tumor initiating capacity and metastasis of estrogen receptor-negative mammary carcinoma cells. Cancer Lett. 2015, 365, 182-189. [CrossRef] [PubMed]

12. Divisova, J.; Kuiatse, I.; Lazard, Z.; Weiss, H.; Vreeland, F.; Hadsell, D.L.; Schiff, R.; Osborne, C.K.; Lee, A.V. The growth hormone receptor antagonist pegvisomant blocks both mammary gland development and MCF-7 breast cancer xenograft growth. Breast Cancer Res. Treat. 2006, 98, 315-327. [CrossRef] [PubMed]

13. Emerman, J.T.; Leahy, M.; Gout, P.W.; Bruchovsky, N. Elevated growth hormone levels in sera from breast cancer patients. Horm. Metab. Res. 1985, 17, 421-424. [CrossRef] [PubMed]

14. Zhang, X.; Mehta, R.G.; Lantvit, D.D.; Coschigano, K.T.; Kopchick, J.J.; Green, J.E.; Hedayat, S.; Christov, K.T.; Ray, V.H.; Unterman, T.G.; et al. Inhibition of estrogen-independent mammary carcinogenesis by disruption of growth hormone signaling. Carcinogenesis 2007, 28, 143-150. [CrossRef]

15. Waters, M.J.; Conway-Campbell, B.L. The oncogenic potential of autocrine human growth hormone in breast cancer. Proc. Natl. Acad. Sci. USA 2004, 101, 14992-14993. [CrossRef]

16. Wang, Z.; Prins, G.S.; Coschigano, K.T.; Kopchick, J.J.; Green, J.E.; Ray, V.H.; Hedayat, S.; Christov, K.T.; Unterman, T.G.; Swanson, S.M. Disruption of growth hormone signaling retards early stages of prostate carcinogenesis in the C3(1)/T antigen mouse. Endocrinology 2005, 146, 5188-5196. [CrossRef]

17. Weiss-Messer, E.; Merom, O.; Adi, A.; Karry, R.; Bidosee, M.; Ber, R.; Kaploun, A.; Stein, A.; Barkey, R.J. Growth hormone (GH) receptors in prostate cancer: Gene expression in human tissues and cell lines and characterization, GH signaling and androgen receptor regulation in LNCaP cells. Mol. Cell. Endocrinol. 2004, 220, 109-123. [CrossRef]

18. Wu, X.; Liu, F.; Yao, X.; Li, W.; Chen, C. Growth hormone receptor expression is up-regulated during tumorigenesis of human colorectal cancer. J. Surg. Res. 2007, 143, 294-299. [CrossRef]

19. Yang, X.; Liu, F.; Xu, Z.; Chen, C.; Li, G.; Wu, X.; Li, J. Growth hormone receptor expression in human colorectal cancer. Dig. Dis. Sci. 2004, 49, 1493-1498. [CrossRef]

20. Lea, R.W.; Dawson, T.; Martinez-Moreno, C.G.; El-Abry, N.; Harvey, S. Growth hormone and cancer: GH production and action in glioma? Gen. Comp. Endocrinol. 2015, 220, 119-123. [CrossRef]

21. Subramani, R.; Lopez-Valdez, R.; Salcido, A.; Boopalan, T.; Arumugam, A.; Nandy, S.; Lakshmanaswamy, R. Growth hormone receptor inhibition decreases the growth and metastasis of pancreatic ductal adenocarcinoma. Exp. Mol. Med. 2014, 46, e117. [CrossRef] [PubMed]

22. Dal, J.; Leisner, M.Z.; Hermansen, K.; Farkas, D.K.; Bengtsen, M.; Kistorp, C.; Nielsen, E.H.; Andersen, M.; Feldt-Rasmussen, U.; Dekkers, O.M.; et al. Cancer Incidence in Patients With Acromegaly: A Cohort Study and Meta-Analysis of the Literature. J. Clin. Endocrinol. Metab. 2018, 103, 2182-2188. [CrossRef] [PubMed]

23. Chen, Y.J.; You, M.L.; Chong, Q.Y.; Pandey, V.; Zhuang, Q.S.; Liu, D.X.; Ma, L.; Zhu, T.; Lobie, P.E. Autocrine Human Growth Hormone Promotes Invasive and Cancer Stem Cell-Like Behavior of Hepatocellular Carcinoma Cells by STAT3 Dependent Inhibition of CLAUDIN-1 Expression. Int. J. Mol. Sci. 2017, 18, 1274. [CrossRef] [PubMed]

24. Pandey, V.; Perry, J.K.; Mohankumar, K.M.; Kong, X.J.; Liu, S.M.; Wu, Z.S.; Mitchell, M.D.; Zhu, T.; Lobie, P.E. Autocrine human growth hormone stimulates oncogenicity of endometrial carcinoma cells. Endocrinology 2008, 149, 3909-3919. [CrossRef]

25. Tang, J.Z.; Kong, X.J.; Banerjee, A.; Muniraj, N.; Pandey, V.; Steiner, M.; Perry, J.K.; Zhu, T.; Liu, D.X.; Lobie, P.E. STAT3alpha is oncogenic for endometrial carcinoma cells and mediates the oncogenic effects of autocrine human growth hormone. Endocrinology 2010, 151, 4133-4145. [CrossRef]

26. Sakharova, A.A.; Horowitz, J.F.; Surya, S.; Goldenberg, N.; Harber, M.P.; Symons, K.; Barkan, A. Role of growth hormone in regulating lipolysis, proteolysis, and hepatic glucose production during fasting. J. Clin. Endocrinol. Metab. 2008, 93, 2755-2759. [CrossRef] 
27. Le Roith, D.; Bondy, C.; Yakar, S.; Liu, J.L.; Butler, A. The somatomedin hypothesis: 2001. Endocr. Rev. 2001, 22, 53-74. [CrossRef]

28. Zhu, T.; Goh, E.L.; Graichen, R.; Ling, L.; Lobie, P.E. Signal transduction via the growth hormone receptor. Cell Signal 2001, 13, 599-616. [CrossRef]

29. Dehkhoda, F.; Lee, C.M.M.; Medina, J.; Brooks, A.J. The Growth Hormone Receptor: Mechanism of Receptor Activation, Cell Signaling, and Physiological Aspects. Front. Endocrinol. 2018, 9, 35. [CrossRef]

30. Barclay, J.L.; Kerr, L.M.; Arthur, L.; Rowland, J.E.; Nelson, C.N.; Ishikawa, M.; d'Aniello, E.M.; White, M.; Noakes, P.G.; Waters, M.J. In vivo targeting of the growth hormone receptor (GHR) Box1 sequence demonstrates that the GHR does not signal exclusively through JAK2. Mol. Endocrinol. 2010, 24, $204-217$. [CrossRef]

31. Arnaldez, F.I.; Helman, L.J. Targeting the insulin growth factor receptor 1. Hematol. Oncol. Clin. N. Am. 2012, 26, 527-542, vii-viii. [CrossRef] [PubMed]

32. Junnila, R.K.; List, E.O.; Berryman, D.E.; Murrey, J.W.; Kopchick, J.J. The GH/IGF-1 axis in ageing and longevity. Nat. Rev. Endocrinol. 2013, 9, 366-376. [CrossRef] [PubMed]

33. Yang, Y.; Yee, D. Targeting insulin and insulin-like growth factor signaling in breast cancer. J. Mammary Gland Biol. Neoplasia 2012, 17, 251-261. [CrossRef] [PubMed]

34. Lupu, F.; Terwilliger, J.D.; Lee, K.; Segre, G.V.; Efstratiadis, A. Roles of growth hormone and insulin-like growth factor 1 in mouse postnatal growth. Dev. Biol. 2001, 229, 141-162. [CrossRef]

35. Clark, R.G.; Mortensen, D.L.; Carlsson, L.M. Insulin-like growth factor-1 and growth hormone (GH) have distinct and overlapping anabolic effects in GH-deficient rats. Endocrine 1995, 3, 297-304. [CrossRef]

36. Palmer, A.J.; Chung, M.Y.; List, E.O.; Walker, J.; Okada, S.; Kopchick, J.J.; Berryman, D.E. Age-related changes in body composition of bovine growth hormone transgenic mice. Endocrinology 2009, 150, 1353-1360. [CrossRef]

37. Naar, E.M.; Bartke, A.; Majumdar, S.S.; Buonomo, F.C.; Yun, J.S.; Wagner, T.E. Fertility of transgenic female mice expressing bovine growth hormone or human growth hormone variant genes. Biol. Reprod. 1991, 45, 178-187. [CrossRef]

38. Zhou, Y.; Xu, B.C.; Maheshwari, H.G.; He, L.; Reed, M.; Lozykowski, M.; Okada, S.; Cataldo, L.; Coschigamo, K.; Wagner, T.E.; et al. A mammalian model for Laron syndrome produced by targeted disruption of the mouse growth hormone receptor/binding protein gene (the Laron mouse). Proc. Natl. Acad. Sci. USA 1997, 94, 13215-13220. [CrossRef]

39. Basu, R.; Qian, Y.; Kopchick, J.J. Mechanisms In Endocrinology: Lessons from growth hormone receptor gene-disrupted mice: Are there benefits of endocrine defects? Eur. J. Endocrinol. 2018, 178, R155-R181. [CrossRef]

40. Basu, R.; Kopchick, J.J. The effects of growth hormone on therapy resistance in cancer. Cancer Drug Resist. 2019, 2, 827-846. [CrossRef]

41. Wu, Z.S.; Yang, K.; Wan, Y.; Qian, P.X.; Perry, J.K.; Chiesa, J.; Mertani, H.C.; Zhu, T.; Lobie, P.E. Tumor expression of human growth hormone and human prolactin predict a worse survival outcome in patients with mammary or endometrial carcinoma. J. Clin. Endocrinol. Metab. 2011, 96, E1619-E1629. [CrossRef] [PubMed]

42. Chesnokova, V.; Zonis, S.; Barrett, R.J.; Gleeson, J.P.; Melmed, S. Growth Hormone Induces Colon DNA Damage Independent of IGF-1. Endocrinology 2019, 160, 1439-1447. [CrossRef] [PubMed]

43. Chesnokova, V.; Melmed, S. Growth hormone in the tumor microenvironment. Arch. Endocrinol. Metab. 2019, 63, 568-575. [CrossRef] [PubMed]

44. Chesnokova, V.; Zonis, S.; Barrett, R.; Kameda, H.; Wawrowsky, K.; Ben-Shlomo, A.; Yamamoto, M.; Gleeson, J.; Bresee, C.; Gorbunova, V.; et al. Excess growth hormone suppresses DNA damage repair in epithelial cells. JCI Insight 2019, 4. [CrossRef]

45. Chesnokova, V.; Zonis, S.; Zhou, C.; Recouvreux, M.V.; Ben-Shlomo, A.; Araki, T.; Barrett, R.; Workman, M.; Wawrowsky, K.; Ljubimov, V.A.; et al. Growth hormone is permissive for neoplastic colon growth. Proc. Natl. Acad. Sci. USA 2016, 113, E3250-E3259. [CrossRef]

46. Chiesa, J.; Ferrer, C.; Arnould, C.; Vouyovitch, C.M.; Diaz, J.J.; Gonzalez, S.; Mares, P.; Morel, G.; Wu, Z.S.; $\mathrm{Zhu}, \mathrm{T}$; et al. Autocrine proliferative effects of hGH are maintained in primary cultures of human mammary carcinoma cells. J. Clin. Endocrinol. Metab. 2011, 96, E1418-E1426. [CrossRef] 
47. Bougen, N.M.; Steiner, M.; Pertziger, M.; Banerjee, A.; Brunet-Dunand, S.E.; Zhu, T.; Lobie, P.E.; Perry, J.K. Autocrine human GH promotes radioresistance in mammary and endometrial carcinoma cells. Endocr. Relat. Cancer 2012, 19, 625-644. [CrossRef]

48. Bougen, N.M.; Yang, T.; Chen, H.; Lobie, P.E.; Perry, J.K. Autocrine human growth hormone reduces mammary and endometrial carcinoma cell sensitivity to mitomycin C. Oncol Rep 2011, 26, 487-493. [CrossRef]

49. Perry, J.K.; Mohankumar, K.M.; Emerald, B.S.; Mertani, H.C.; Lobie, P.E. The contribution of growth hormone to mammary neoplasia. J. Mammary Gland Biol. Neoplasia 2008, 13, 131-145. [CrossRef]

50. Perry, J.K.; Wu, Z.S.; Mertani, H.C.; Zhu, T.; Lobie, P.E. Tumour-Derived Human Growth Hormone As a Therapeutic Target in Oncology. Trends Endocrinol. Metab. 2017, 28, 587-596. [CrossRef]

51. Zhu, T.; Starling-Emerald, B.; Zhang, X.; Lee, K.O.; Gluckman, P.D.; Mertani, H.C.; Lobie, P.E. Oncogenic transformation of human mammary epithelial cells by autocrine human growth hormone. Cancer Res. 2005, 65, 317-324. [PubMed]

52. Zhu, Z.; Mukhina, S.; Zhu, T.; Mertani, H.C.; Lee, K.O.; Lobie, P.E. p44/42 MAP kinase-dependent regulation of catalase by autocrine human growth hormone protects human mammary carcinoma cells from oxidative stress-induced apoptosis. Oncogene 2005, 24, 3774-3785. [CrossRef] [PubMed]

53. Xu, X.Q.; Emerald, B.S.; Goh, E.L.; Kannan, N.; Miller, L.D.; Gluckman, P.D.; Liu, E.T.; Lobie, P.E. Gene expression profiling to identify oncogenic determinants of autocrine human growth hormone in human mammary carcinoma. J. Biol. Chem. 2005, 280, 23987-24003. [CrossRef] [PubMed]

54. Kaulsay, K.K.; Mertani, H.C.; Tornell, J.; Morel, G.; Lee, K.O.; Lobie, P.E. Autocrine stimulation of human mammary carcinoma cell proliferation by human growth hormone. Exp. Cell Res. 1999, 250, 35-50. [CrossRef] [PubMed]

55. American Cancer Society. Cancer Facts \& Figures; The Society: Atlanta, GA, USA, 2020.

56. Sustarsic, E.G.; Junnila, R.K.; Kopchick, J.J. Human metastatic melanoma cell lines express high levels of growth hormone receptor and respond to GH treatment. Biochem. Biophys. Res. Commun. 2013, 441, 144-150. [CrossRef] [PubMed]

57. Basu, R.; Wu, S.; Kopchick, J.J. Targeting growth hormone receptor in human melanoma cells attenuates tumor progression and epithelial mesenchymal transition via suppression of multiple oncogenic pathways. Oncotarget 2017, 8, 21579-21598. [CrossRef]

58. Basu, R.; Baumgaertel, N.; Wu, S.; Kopchick, J.J. Growth Hormone Receptor Knockdown Sensitizes Human Melanoma Cells to Chemotherapy by Attenuating Expression of ABC Drug Efflux Pumps. Horm. Cancer 2017, 8, 143-156. [CrossRef] [PubMed]

59. Basu, R.; Kulkarni, P.; Qian, Y.; Walsh, C.; Arora, P.; Davis, E.; Duran-Ortiz, S.; Funk, K.; Ibarra, D.; Kruse, C.; et al. Growth Hormone Upregulates Melanocyte-Inducing Transcription Factor Expression and Activity via JAK2-STAT5 and SRC Signaling in GH Receptor-Positive Human Melanoma. Cancers 2019, 11, 1352. [CrossRef]

60. Le Coz, V.; Zhu, C.; Devocelle, A.; Vazquez, A.; Boucheix, C.; Azzi, S.; Gallerne, C.; Eid, P.; Lecourt, S.; Giron-Michel, J. IGF-1 contributes to the expansion of melanoma-initiating cells through an epithelial-mesenchymal transition process. Oncotarget 2016, 7, 82511-82527. [CrossRef]

61. Zhao, K.; Wei, L.; Hui, H.; Dai, Q.; You, Q.D.; Guo, Q.L.; Lu, N. Wogonin suppresses melanoma cell B16-F10 invasion and migration by inhibiting Ras-medicated pathways. PLoS ONE 2014, 9, e106458. [CrossRef]

62. Carter-Su, C.; Schwartz, J.; Argetsinger, L.S. Growth hormone signaling pathways. Growth Horm. IGF Res. 2016, 28, 11-15. [CrossRef] [PubMed]

63. Kim, S.H.; Park, M.J. Effects of growth hormone on glucose metabolism and insulin resistance in human. Ann. Pediatr. Endocrinol. Metab. 2017, 22, 145-152. [CrossRef] [PubMed]

64. Sag, D.; Cekic, C.; Wu, R.; Linden, J.; Hedrick, C.C. The cholesterol transporter ABCG1 links cholesterol homeostasis and tumour immunity. Nat. Commun. 2015, 6, 6354. [CrossRef] [PubMed]

65. Wu, C.P.; Ambudkar, S.V. The pharmacological impact of ATP-binding cassette drug transporters on vemurafenib-based therapy. Acta Pharm. Sin. B 2014, 4, 105-111. [CrossRef]

66. Landreville, S.; Agapova, O.A.; Kneass, Z.T.; Salesse, C.; Harbour, J.W. ABCB1 identifies a subpopulation of uveal melanoma cells with high metastatic propensity. Pigm. Cell Melanoma R 2011, 24, 430-437. [CrossRef] [PubMed]

67. Elliott, A.M.; Ai-Hajj, M.A. ABCB8 Mediates Doxorubicin Resistance in Melanoma Cells by Protecting the Mitochondrial Genome. Mol. Cancer Res. 2009, 7, 79-87. [CrossRef] 
68. Monzani, E.; Facchetti, F.; Galmozzi, E.; Corsini, E.; Benetti, A.; Cavazzin, C.; Gritti, A.; Piccinini, A.; Porro, D.; Santinami, M.; et al. Melanoma contains CD133 and ABCG2 positive cells with enhanced tumourigenic potential. Eur. J. Cancer 2007, 43, 935-946. [CrossRef]

69. Szakacs, G.; Annereau, J.P.; Lababidi, S.; Shankavaram, U.; Arciello, A.; Bussey, K.J.; Reinhold, W.; Guo, Y.; Kruh, G.D.; Reimers, M.; et al. Predicting drug sensitivity and resistance: Profiling ABC transporter genes in cancer cells. Cancer Cell 2004, 6, 129-137. [CrossRef]

70. Liedert, B.; Materna, V.; Schadendorf, D.; Thomale, J.; Lage, H. Overexpression of cMOAT (MRP2/ABCC2) is associated with decreased formation of platinum-DNA adducts and decreased G2-arrest in melanoma cells resistant to cisplatin. J. Investig. Dermatol. 2003, 121, 172-176. [CrossRef]

71. Arumugam, A.; Subramani, R.; Nandy, S.B.; Terreros, D.; Dwivedi, A.K.; Saltzstein, E.; Lakshmanaswamy, R. Silencing growth hormone receptor inhibits estrogen receptor negative breast cancer through ATP-binding cassette sub-family G member 2. Exp. Mol. Med. 2019, 51, 2. [CrossRef]

72. Du, J.; Shi, H.R.; Ren, F.; Wang, J.L.; Wu, Q.H.; Li, X.; Zhang, R.T. Inhibition of the IGF signaling pathway reverses cisplatin resistance in ovarian cancer cells. BMC Cancer 2017, 17, 851. [CrossRef] [PubMed]

73. Benabbou, N.; Mirshahi, P.; Cadillon, M.; Soria, J.; Therwath, A.; Mirshahi, M. Hospicells promote upregulation of the ATP-binding cassette genes by insulin-like growth factor-I via the JAK2/STAT3 signaling pathway in an ovarian cancer cell line. Int. J. Oncol. 2013, 43, 685-694. [CrossRef] [PubMed]

74. Shen, K.; Cui, D.; Sun, L.; Lu, Y.; Han, M.; Liu, J. Inhibition of IGF-IR increases chemosensitivity in human colorectal cancer cells through MRP-2 promoter suppression. J. Cell Biochem. 2012, 113, 2086-2097. [CrossRef] [PubMed]

75. Benabbou, N.; Mirshahi, P.; Bordu, C.; Faussat, A.M.; Tang, R.; Therwath, A.; Soria, J.; Marie, J.P.; Mirshahi, M. A subset of bone marrow stromal cells regulate ATP-binding cassette gene expression via insulin-like growth factor-I in a leukemia cell line. Int. J. Oncol. 2014, 45, 1372-1380. [CrossRef]

76. Brittain, A.L.; Basu, R.; Qian, Y.; Kopchick, J.J. Growth Hormone and the Epithelial-to-Mesenchymal Transition. J. Clin. Endocrinol. Metab. 2017. [CrossRef]

77. Mukhina, S.; Mertani, H.C.; Guo, K.; Lee, K.O.; Gluckman, P.D.; Lobie, P.E. Phenotypic conversion of human mammary carcinoma cells by autocrine human growth hormone. Proc. Natl. Acad. Sci. USA 2004, 101, 15166-15171. [CrossRef]

78. Zhang, W.; Qian, P.; Zhang, X.; Zhang, M.; Wang, H.; Wu, M.; Kong, X.; Tan, S.; Ding, K.; Perry, J.K.; et al. Autocrine/Paracrine Human Growth Hormone-stimulated MicroRNA 96-182-183 Cluster Promotes Epithelial-Mesenchymal Transition and Invasion in Breast Cancer. J. Biol. Chem. 2015, 290, 13812-13829. [CrossRef]

79. Wang, J.J.; Chong, Q.Y.; Sun, X.B.; You, M.L.; Pandey, V.; Chen, Y.J.; Zhuang, Q.S.; Liu, D.X.; Ma, L.; Wu, Z.S.; et al. Autocrine hGH stimulates oncogenicity, epithelial-mesenchymal transition and cancer stem cell-like behavior in human colorectal carcinoma. Oncotarget 2017, 8, 103900-103918. [CrossRef]

80. Liao, G.; Wang, M.; Ou, Y.; Zhao, Y. IGF-1-induced epithelial-mesenchymal transition in MCF-7 cells is mediated by MUC1. Cell Signal. 2014, 26, 2131-2137. [CrossRef]

81. Ford, N.A.; Nunez, N.P.; Holcomb, V.B.; Hursting, S.D. IGF1 dependence of dietary energy balance effects on murine Met1 mammary tumor progression, epithelial-to-mesenchymal transition, and chemokine expression. Endocr. Relat. Cancer 2013, 20,39-51. [CrossRef]

82. Yao, C.; Su, L.; Shan, J.; Zhu, C.; Liu, L.; Liu, C.; Xu, Y.; Yang, Z.; Bian, X.; Shao, J.; et al. IGF/STAT3/NANOG/Slug Signaling Axis Simultaneously Controls Epithelial-Mesenchymal Transition and Stemness Maintenance in Colorectal Cancer. Stem Cells 2016, 34, 820-831. [CrossRef] [PubMed]

83. Park, G.B.; Kim, D. Insulin-like growth factor-1 activates different catalytic subunits p110 of PI3K in a cell-type-dependent manner to induce lipogenesis-dependent epithelial-mesenchymal transition through the regulation of ADAM10 and ADAM17. Mol. Cell. Biochem. 2018, 439, 199-211. [CrossRef] [PubMed]

84. Nurwidya, F.; Takahashi, F.; Kobayashi, I.; Murakami, A.; Kato, M.; Minakata, K.; Nara, T.; Hashimoto, M.; Yagishita, S.; Baskoro, H.; et al. Treatment with insulin-like growth factor 1 receptor inhibitor reverses hypoxia-induced epithelial-mesenchymal transition in non-small cell lung cancer. Biochem. Biophys. Res. Commun. 2014, 455, 332-338. [CrossRef] [PubMed]

85. Zhou, J.; Wang, J.; Zeng, Y.; Zhang, X.; Hu, Q.; Zheng, J.; Chen, B.; Xie, B.; Zhang, W.M. Implication of epithelial-mesenchymal transition in IGF1R-induced resistance to EGFR-TKIs in advanced non-small cell lung cancer. Oncotarget 2015, 6, 44332-44345. [CrossRef] [PubMed] 
86. Li, C.; Li, J.; Wu, D.; Han, G. The involvement of survivin in insulin-like growth factor 1-induced epithelial-mesenchymal transition in gastric cancer. Tumour Biol. 2016, 37, 1091-1096. [CrossRef]

87. Li, H.; Xu, L.; Zhao, L.; Ma, Y.; Zhu, Z.; Liu, Y.; Qu, X. Insulin-like growth factor-I induces epithelial to mesenchymal transition via GSK-3beta and ZEB2 in the BGC-823 gastric cancer cell line. Oncol. Lett. 2015, 9, 143-148. [CrossRef]

88. Li, H.; Xu, L.; Li, C.; Zhao, L.; Ma, Y.; Zheng, H.; Li, Z.; Zhang, Y.; Wang, R.; Liu, Y.; et al. Ubiquitin ligase Cbl-b represses IGF-I-induced epithelial mesenchymal transition via ZEB2 and microRNA-200c regulation in gastric cancer cells. Mol. Cancer 2014, 13, 136. [CrossRef]

89. Graham, T.R.; Zhau, H.E.; Odero-Marah, V.A.; Osunkoya, A.O.; Kimbro, K.S.; Tighiouart, M.; Liu, T.; Simons, J.W.; O'Regan, R.M. Insulin-like growth factor-I-dependent up-regulation of ZEB1 drives epithelial-to-mesenchymal transition in human prostate cancer cells. Cancer Res. 2008, 68, 2479-2488. [CrossRef]

90. Zhau, H.E.; Odero-Marah, V.; Lue, H.W.; Nomura, T.; Wang, R.; Chu, G.; Liu, Z.R.; Zhou, B.P.; Huang, W.C.; Chung, L.W. Epithelial to mesenchymal transition (EMT) in human prostate cancer: Lessons learned from ARCaP model. Clin. Exp. Metastasis 2008, 25, 601-610. [CrossRef]

91. Liu, F.; Sun, Y.; Liu, B.; Lu, J.; Li, H.; Zhu, H.; Gao, H.; Zhou, X.; Chang, H. Insulin-like growth factor-1 induces epithelial-mesenchymal transition in hepatocellular carcinoma by activating survivin. Oncol. Rep. 2018, 40, 952-958. [CrossRef]

92. Lin, Y.C.; Lin, J.C.; Hung, C.M.; Chen, Y.; Liu, L.C.; Chang, T.C.; Kao, J.Y.; Ho, C.T.; Way, T.D. Osthole inhibits insulin-like growth factor-1-induced epithelial to mesenchymal transition via the inhibition of PI3K/Akt signaling pathway in human brain cancer cells. J. Agric. Food Chem. 2014, 62, 5061-5071. [CrossRef] [PubMed]

93. Alonso, S.R.; Tracey, L.; Ortiz, P.; Perez-Gomez, B.; Palacios, J.; Pollan, M.; Linares, J.; Serrano, S.; Saez-Castillo, A.I.; Sanchez, L.; et al. A high-throughput study in melanoma identifies epithelial-mesenchymal transition as a major determinant of metastasis. Cancer Res. 2007, 67, 3450-3460. [CrossRef] [PubMed]

94. Li, F.Z.; Dhillon, A.S.; Anderson, R.L.; McArthur, G.; Ferrao, P.T. Phenotype switching in melanoma: Implications for progression and therapy. Front. Oncol. 2015, 5, 31. [CrossRef] [PubMed]

95. Caramel, J.; Papadogeorgakis, E.; Hill, L.; Browne, G.J.; Richard, G.; Wierinckx, A.; Saldanha, G.; Osborne, J.; Hutchinson, P.; Tse, G.; et al. A Switch in the Expression of Embryonic EMT-Inducers Drives the Development of Malignant Melanoma. Cancer Cell 2013, 24, 466-480. [CrossRef]

96. Chen, Y.; Lu, X.; Montoya-Durango, D.E.; Liu, Y.H.; Dean, K.C.; Darling, D.S.; Kaplan, H.J.; Dean, D.C.; Gao, L.; Liu, Y. ZEB1 Regulates Multiple Oncogenic Components Involved in Uveal Melanoma Progression. Sci. Rep. 2017, 7, 45. [CrossRef]

97. Wauthier, V.; Waxman, D.J. Sex-specific early growth hormone response genes in rat liver. Mol. Endocrinol. 2008, 22, 1962-1974. [CrossRef]

98. Waxman, D.J.; O'Connor, C. Growth hormone regulation of sex-dependent liver gene expression. Mol. Endocrinol. 2006, 20, 2613-2629. [CrossRef]

99. Tang, Z.; Li, C.; Kang, B.; Gao, G.; Li, C.; Zhang, Z. GEPIA: A web server for cancer and normal gene expression profiling and interactive analyses. Nucleic Acids Res. 2017, 45, W98-W102. [CrossRef]

100. Green, H.; Morikawa, M.; Nixon, T. A dual effector theory of growth-hormone action. Differentiation 1985, 29, 195-198. [CrossRef]

101. Guevara-Aguirre, J.; Balasubramanian, P.; Guevara-Aguirre, M.; Wei, M.; Madia, F.; Cheng, C.W.; Hwang, D.; Martin-Montalvo, A.; Saavedra, J.; Ingles, S.; et al. Growth hormone receptor deficiency is associated with a major reduction in pro-aging signaling, cancer, and diabetes in humans. Sci. Transl. Med. 2011, 3, 70ra13. [CrossRef]

102. Steuerman, R.; Shevah, O.; Laron, Z. Congenital IGF1 deficiency tends to confer protection against post-natal development of malignancies. Eur. J. Endocrinol. 2011, 164, 485-489. [CrossRef] [PubMed]

103. Lu, M.; Flanagan, J.U.; Langley, R.J.; Hay, M.P.; Perry, J.K. Targeting growth hormone function: Strategies and therapeutic applications. Signal Transduct. Target Ther. 2019, 4, 3. [CrossRef] [PubMed]

104. Friend, K.E. Cancer and the potential place for growth hormone receptor antagonist therapy. Growth Horm. IGF Res. 2001, 11 (Suppl. A), S121-S123. [CrossRef]

105. Holly, J.; Perks, C. Growth hormone and cancer: Are we asking the right questions? Clin. Endocrinol. 2006, 64, 122-124. [CrossRef] 
106. Holly, J.M.; Gunnell, D.J.; Davey Smith, G. Growth hormone, IGF-I and cancer. Less intervention to avoid cancer? More intervention to prevent cancer? J. Endocrinol. 1999, 162, 321-330. [CrossRef]

107. Critical evaluation of the safety of recombinant human growth hormone administration: Statement from the Growth Hormone Research Society. J. Clin. Endocrinol. Metab. 2001, 86, 1868-1870. [CrossRef]

108. Stochholm, K.; Johannsson, G. Reviewing the safety of GH replacement therapy in adults. Growth Horm. IGF Res. 2015, 25, 149-157. [CrossRef]

109. Raman, S.; Grimberg, A.; Waguespack, S.G.; Miller, B.S.; Sklar, C.A.; Meacham, L.R.; Patterson, B.C. Risk of Neoplasia in Pediatric Patients Receiving Growth Hormone Therapy-A Report From the Pediatric Endocrine Society Drug and Therapeutics Committee. J. Clin. Endocrinol. Metab. 2015, 100, 2192-2203. [CrossRef]

110. Sklar, C.A.; Mertens, A.C.; Mitby, P.; Occhiogrosso, G.; Qin, J.; Heller, G.; Yasui, Y.; Robison, L.L. Risk of disease recurrence and second neoplasms in survivors of childhood cancer treated with growth hormone: A report from the Childhood Cancer Survivor Study. J. Clin. Endocrinol. Metab. 2002, 87, 3136-3141. [CrossRef]

111. Cao, Y.; Nimptsch, K.; Shui, I.M.; Platz, E.A.; Wu, K.; Pollak, M.N.; Kenfield, S.A.; Stampfer, M.J.; Giovannucci, E.L. Prediagnostic plasma IGFBP-1, IGF-1 and risk of prostate cancer. Int. J. Cancer 2015, 136, 2418-2426. [CrossRef]

112. Gao, Y.; Katki, H.; Graubard, B.; Pollak, M.; Martin, M.; Tao, Y.; Schoen, R.E.; Church, T.; Hayes, R.B.; Greene, M.H.; et al. Serum IGF1, IGF2 and IGFBP3 and risk of advanced colorectal adenoma. Int. J. Cancer 2012, 131, 105-113. [CrossRef] [PubMed]

113. Clemmons, D.R. Modifying IGF1 activity: An approach to treat endocrine disorders, atherosclerosis and cancer. Nat. Rev. Drug Discov. 2007, 6, 821-833. [CrossRef] [PubMed]

114. Osher, E.; Macaulay, V.M. Therapeutic Targeting of the IGF Axis. Cells 2019, 8, 895. [CrossRef] [PubMed]

115. Levine, M.E.; Suarez, J.A.; Brandhorst, S.; Balasubramanian, P.; Cheng, C.W.; Madia, F.; Fontana, L.; Mirisola, M.G.; Guevara-Aguirre, J.; Wan, J.; et al. Low protein intake is associated with a major reduction in IGF-1, cancer, and overall mortality in the 65 and younger but not older population. Cell Metab. 2014, 19, 407-417. [CrossRef] [PubMed]

116. Milman, S.; Atzmon, G.; Huffman, D.M.; Wan, J.; Crandall, J.P.; Cohen, P.; Barzilai, N. Low insulin-like growth factor-1 level predicts survival in humans with exceptional longevity. Aging Cell 2014, 13, 769-771. [CrossRef] [PubMed]

117. Pollak, M. Insulin and insulin-like growth factor signalling in neoplasia. Nat. Rev. Cancer 2008, 8, 915-928. [CrossRef]

118. Beckwith, H.; Yee, D. Minireview: Were the IGF Signaling Inhibitors All Bad? Mol. Endocrinol. 2015, 29, 1549-1557. [CrossRef]

119. Chhabra, Y.; Nelson, C.N.; Plescher, M.; Barclay, J.L.; Smith, A.G.; Andrikopoulos, S.; Mangiafico, S.; Waxman, D.J.; Brooks, A.J.; Waters, M.J. Loss of growth hormone-mediated signal transducer and activator of transcription 5 (STAT5) signaling in mice results in insulin sensitivity with obesity. FASEB J. 2019, 33, 6412-6430. [CrossRef]

120. Adamson, U. On the diabetogenic effect of growth hormone in man: Effects of growth hormone of glucagon and insulin secretion. Eur. J. Clin. Investig. 1981, 11, 115-119. [CrossRef]

121. Bornstein, J.; Armstrong, J.M.; Gould, M.K.; Harcourt, J.A.; Jones, M.D. Mechanism of the diabetogenic action of growth hormone. I. Effect of polypeptides derived from growth hormone on glycolysis in muscle. Biochim. Biophys. Acta 1969, 192, 265-270. [CrossRef]

122. Jara, A.; Liu, X.; Sim, D.; Benner, C.M.; Duran-Ortiz, S.; Qian, Y.; List, E.O.; Berryman, D.E.; Kim, J.K.; Kopchick, J.J. Cardiac-Specific Disruption of GH Receptor Alters Glucose Homeostasis While Maintaining Normal Cardiac Performance in Adult Male Mice. Endocrinology 2016, 157, 1929-1941. [CrossRef] [PubMed]

123. Qian, Y.; Wang, X.; Liu, Y.; Li, Y.; Colvin, R.A.; Tong, L.; Wu, S.; Chen, X. Extracellular ATP is internalized by macropinocytosis and induces intracellular ATP increase and drug resistance in cancer cells. Cancer Lett 2014, 351, 242-251. [CrossRef] [PubMed]

124. Vonk, A.G.; Wieland, C.W.; Versteegen, M.; Verschueren, I.C.; Netea, M.G.; Joosten, L.A.B.; Verweij, P.E.; Kullberg, B.J. Influence of endogenous pro-inflammatory cytokines on neutrophil-mediated damage of Candida albicans pseudohyphae, quantified in a modified tetrazolium dye assay. Med. Mycol. 2005, 43, 551-557. [CrossRef] [PubMed] 
125. Qian, Y.; Wang, X.; Li, Y.; Cao, Y.; Chen, X. Extracellular ATP a New Player in Cancer Metabolism: NSCLC Cells Internalize ATP In Vitro and In Vivo Using Multiple Endocytic Mechanisms. Mol. Cancer Res. 2016, 14, 1087-1096. [CrossRef]

126. Liu, Y.; Cao, Y.; Zhang, W.; Bergmeier, S.; Qian, Y.; Akbar, H.; Colvin, R.; Ding, J.; Tong, L.; Wu, S.; et al. A small-molecule inhibitor of glucose transporter 1 downregulates glycolysis, induces cell-cycle arrest, and inhibits cancer cell growth in vitro and in vivo. Mol. Cancer Ther. 2012, 11, 1672-1682. [CrossRef]

127. Wang, J.; Yu, F.; Jia, X.; Iwanowycz, S.; Wang, Y.; Huang, S.; Ai, W.; Fan, D. MicroRNA-155 deficiency enhances the recruitment and functions of myeloid-derived suppressor cells in tumor microenvironment and promotes solid tumor growth. Int. J. Cancer 2015, 136, E602-E613. [CrossRef]

Publisher's Note: MDPI stays neutral with regard to jurisdictional claims in published maps and institutional affiliations.

(C) 2020 by the authors. Licensee MDPI, Basel, Switzerland. This article is an open access article distributed under the terms and conditions of the Creative Commons Attribution (CC BY) license (http://creativecommons.org/licenses/by/4.0/). 